\title{
Production of Larval Herring, Clupea harengus, Along the Maine Coast, 1964-78
}

\author{
J. J. Graham \\ Maine Department of Marine Resources, Fishery Research Laboratory \\ West Boothbay Harbor, Maine, USA 04575
}

\begin{abstract}
The production of larval herring during $1964-78$ is examined in relation to recruitment to the Maine fishery for juveniles. Larval abundance at the beginning of winter, winter larval mortality, larval condition, and spring larval abundance were considered to be the kinds of indices suitable for predicting year-class strength of juvenile herring. Long-term relationships between these indices of larval production and recruitment could not be established because of changes in spawning behavior and a decrease in the coastal herring population during the investigation. A conceptual model of larval herring was developed to illustrate events that contributed to the final strength of larval year-classes just before their metamorphosis into juveniles in late spring. The model was based on the assumptions that the determinant of year-class strength is the level of larval abundance following a density-dependent phase of mortality in autumn and a density-independent phase in winter, and that this level of abundance may be modified by late spawning and the nature of the distribution of larvae along the coast after hatching in the autumn. In addition to providing a rationale for forecasting, the model suggests that the recruitment mechanism primarily responsible for the success of year-classes is the opportunity for larvae to distribute themselves throughout the inshore areas after hatching in coastal waters.
\end{abstract}

\section{Introduction}

In 1962, research on Atlantic herring, Clupea harengus, was greatly expanded along the Maine coast. The expansion was prompted by a drastic decrease in the harvest of "sardine-size" herring in the late 1950's and early 1960's (Anthony, MS 1972). The major hypothesis tested by the research was that the strength of a given herring year-class was established early in its life history, permitting forecasting of recruitment to the fishery from larval abundance or some other correlative index. Efforts in the 1960's culminated in a description of the coastal ecology of larval herring, and the selection of winter mortality, winter condition and spring abundance of larvae as being the kinds of estimates most suitable for anticipating year-class strength (Graham et al., 1972). By the 1970's, the investigation was curtailed and effort was reduced to monitoring winter mortality and spring abundance of larval herring, but winter condition of the larvae was also monitored in the late 1970's.

A long period of sampling (1964-78) was necessary to obtain data which could be evaluated for predictive capabilities. During this period, the size of the herring populations changed considerably. The spawning populations in the western Gulf of Maine were reduced greatly by the early 1970's (Anthony and Waring, 1980), and those of Georges Bank had declined to insignificance by the late 1970's. Nevertheless, the relatively low spawning stocks of the 1970's often produced recruitment to the Maine coastal fishery which was equivalent to that produced by the larger stocks of the 1960's.
The assembled results of 15 years of sampling larval herring along the Maine coast are presented in this paper. Winter mortality and spring abundance of the larvae are discussed in the light of their application to forecasting recruitment. Possible determinants of larval year-class strength are suggested and a conceptual model of annual larval production is given.

\section{Materials and Methods}

Sampling during the 1960's encompassed the relatively long life (6-8 months) of larval herring in Maine waters but concentrated on the chosen indices (winter mortality and spring abundance) in the 1970's. Research in the first decade showed that concentrations of larval herring, hatched in coastal waters beyond the headlands, drifted for various distances along the coast and entered the estuaries and embayments (Graham et al., 1972). They dispersed in winter only to concentrate again in the spring prior to metamorphosis into juveniles which occurs in late spring or early summer. These early studies indicated that winter mortality probably determined the spring abundance of larvae and that the severity of winter mortality was reflected by the condition of the larvae (Graham and Davis, 1971).

\section{Larval herring dispersal in autumn}

In order to relate the estimates of larval herring mortality, obtained during the winter in an inshore estuary, to the coastal population, it was necessary to follow the dispersion of larvae along the coast during 
the autumn. Consequently, four larval herring surveys of the coastal waters of Maine, New Hampshire and Massachusetts (Fig. 1) were conducted during each autumn of 1971 and 1972. The methodology and preliminary results of these surveys were reported by Graham et al. (MS 1972, MS 1973). Essentially, 61-cm Bongo nets (Posgay and Marak, 1980) were towed at 3.5 knots $(108 \mathrm{~m} / \mathrm{min})$ obliquely from a maximum depth of $100 \mathrm{~m}$ or as close to the bottom as was considered prudent in shallow water. The gear was set at 50 $\mathrm{m} / \mathrm{min}$ and retrieved at $10 \mathrm{~m} / \mathrm{min}$. Sampling proceeded from east to west along the coast on a 24-hr basis, except in early September 1972 when it was limited to daylight hours. This limitation applied only to the first survey (2-6 September) when sampling was restricted to 11 stations off eastern Maine, because larvae along central and western Maine were known to hatch later than the time of this survey. Forty-one stations (Fig. 1) were occupied during each of the remaining surveys in 1972 (21-24 September, 18-22 October and 6-12 November). Only the results for the 1972 surveys are illustrated ir. this paper, as the results for the 1971 surveys were essentially the same (Graham et al., MS 1972).

\section{Mortality estimates}

Estimates of larval herring mortality are based on field samples from the Sheepscot River estuary (Fig. 2) during the early winter months of 1964-73 and 1977. Mortality was estimated for the winter period because larval movement is reduced and the rather harsh environment probably has a significant effect on the larval population.

The Sheepscot River estuary was chosen as a representative site for estimating larval mortality because of its central position within the coastal environment (Fig. 2) and the persistent concentration of larvae there throughout their life-history stage. The physical environment differs from west to east along the coast, with greater vertical mixing by tides in the east and greater stratification of the water column in the west (Graham, 1970b). Sherman (1970), in studying the food of larval hering along the Maine coast, found a general decline in zooplankton abundance from west to east from spring to autumn, which was related to an increasingly favorable environment for growth and development of zooplankton from Frenchman Bay westward (Fig. 1). However, environmental

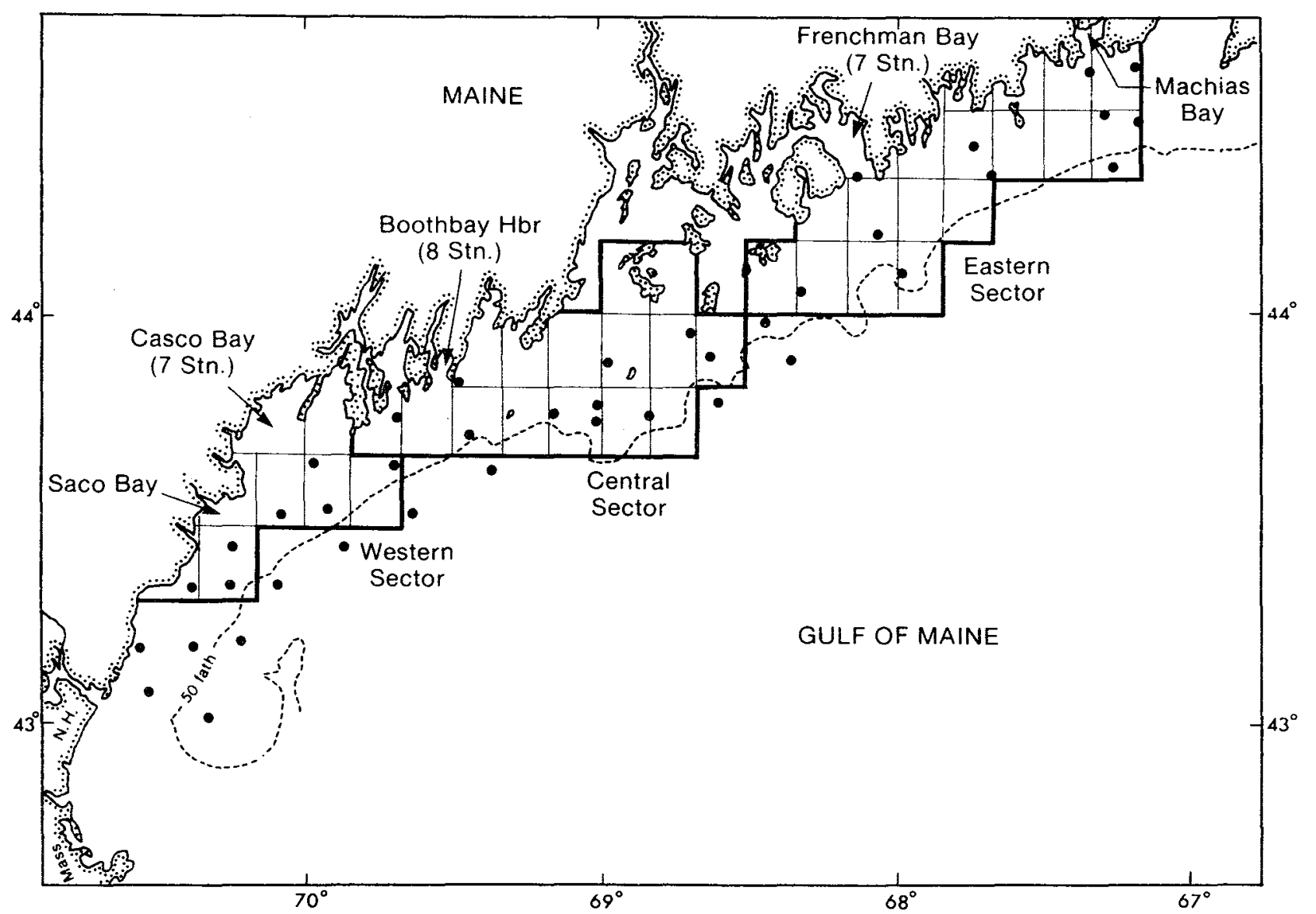

Fig. 1. The coastal Maine region showing the rectangles for spring stratified-random sampling along the coast during $1965-78$, the general locations of the three areas of inshore sampling during the same period, and the actual positions of stations (dots) occupied during the autumn surveys of 1972 . 


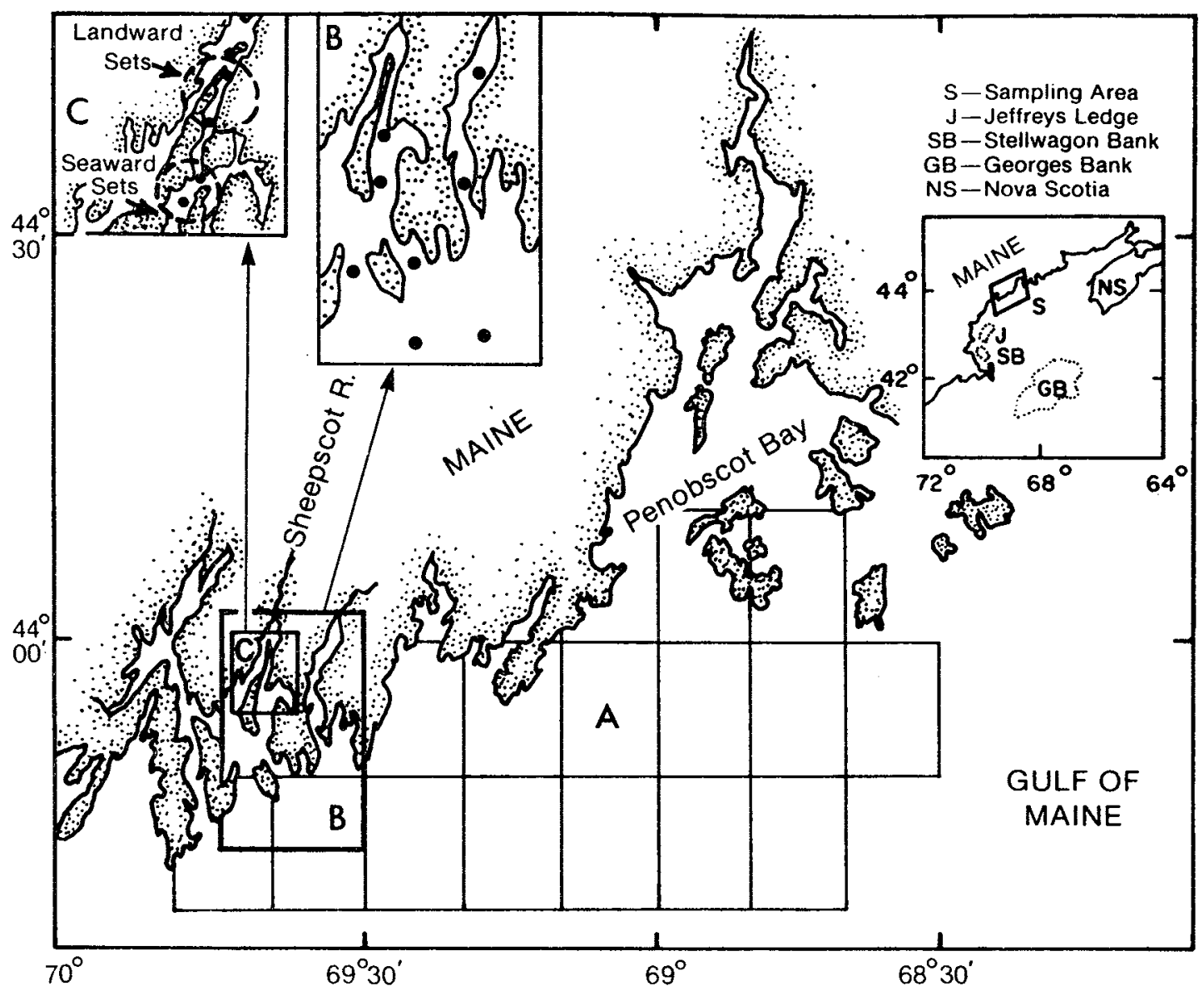

Fig. 2. Areas where monitoring of larval herring abundance was conducted during 1964-78. A, coastai with towed gear in spring. B. inshore (Boothbay area) with towed gear in spring. C, estuarine (Sheepscot River) with buoyed and anchored nets in autumn and winter. (Montsweag Bay is on the western side of the Sheepscot River estuary.)

conditions are relatively uniform along the coast in winter. The Sheepscot River estuary receives herring larvae transported from the eastern coastal sector as well as from the central sector (Graham et al., 1972; Graham and Joule, MS 1981), and sampling along the coast indicated that larval herring were most persistent within the estuary (Graham and Venno, 1968).

Buoyed and anchored nets were used to strain herring larvae from the tidal flows of the estuary, as described by Graham and Venno (1968), Graham and Davis (1971) and Graham (1972a). Essentially, four lines of nets (each line consisting of four nets) were fished at four stations in the estuarine channel. From 1964 to 1970 , the mortality estimates were based on one overnight sampling period in December and another about a month later in January. Subsequently, sampling was conducted during two overnight periods in each month to compensate for the low numbers of larvae evident in the early 1970's. During 1965-67, the gear was set at dusk during slack water, retrieved at the end of the tidal stage, reset during slack water, and retrieved before dawn during slack water. Thus, the nets fished for approximately $6 \mathrm{hr}$ on each flood and ebb tide, yielding a total of 32 samples per night. During 1964 and 1968-78 (except 1973), the gear was set at dusk and retrieved at dawn after the nets had fished during one semidiurnal tidal cycle, thus yielding a total of 16 samples. For the cases where sampling was conducted during two overnight periods in each month, the catch rates were averaged for use in calculating the mortalities.

Graham and Davis (1971) compared mortalities for the 1964-67 year-classes of larval herring in the Sheepscot River estuary by adjusting their estimates to 15-day calendar intervals. For the instantaneous mortalities used in this paper, winter (mid-December to mid-March) was considered as the unit of time and the number of tidal phases during the winter as the environmental time scale. The number of tidal phases appears to be a more realistic scale on which to base larval mortality than one that is chronological. The relationship between these time scales is not constant since four tidal phases exceed 1 day by about $50 \mathrm{~min}$. Catch rates used for estimating mortality were defined 
as the number of larvae caught per $100 \mathrm{~m}^{3}$ of water strained through the nets during an overnight sampling period. Mortality estimates derived from sampling in December and January were projected for the winter period, using the relationship

$$
N_{t}=N_{0} e^{-z t}
$$

where $N_{0}$ is the catch rate for the initial sampling period, $N_{t}$ is the catch rate for the sampling period $t$ tidal phases later, and $z$ is the instantaneous rate of death per tidal phase. The product of $z$ and the number of tidal phases $(t)$ during the 3-month winter period (348 tidal phases) provides an estimate of winter mortality. Seasonal mortalities, based on the number of days between sampling periods, are identical to those based on the number of tidal phases.

\section{Spring abundance of larvae}

Estimates of the relative abundance of herring larvae in the spring were made in 1966-79 from inshore and coastal sampling during daylight along the central Maine coast (Fig. 2). The timing of the surveys in late March to late A pril was intended to ensure that a significant portion of the larval population was available for sampling before metamorphosis into juveniles occurred. The inshore sampling area, containing eight stations, extended $24 \mathrm{~km}$ shoreward from the headlands into the estuaries and embayments. The coastal sampling area, containing 15 stations, extended $24 \mathrm{~km}$ seaward from the headlands. The locations of the sampling stations were intended to overlap the different environments in the eastern and western coastal sectors. On three occasions in the 1960's, an additional inshore or offshore survey was conducted, and the catch rates of larval herring for these double surveys were averaged. Sampling was conducted with a Boothbay Depressor trawl using stepped oblique hauls at $125-185 \mathrm{~m} / \mathrm{min}$, as described by Graham et al. (1972). Characteristics and performance of the trawl were reported by Graham and Vaughn (1966) and Graham (1972b). Two Boothbay Depressor trawls were lost during the spring survey in 1978 and they were replaced by $61-\mathrm{cm}$ Bongo nets (Posgay and Marak, 1980) with other procedures remaining the same.

Prior to 1967, sampling was rather subjective in that the stations tended to be located along towing paths that favored protection of the gear and in localities where previous exploratory sampling indicated that larvae would be abundant. Such sampling estimated larval abundance inaccurately because of the apparent close association between larval distribution and coastal currents (Graham et al., 1972). Consequently, a stratified-random sampling design was introduced in 1967 for the coastal surveys (Table 1).
TABLE 1. Summary of sampling techniques for inshore and coastal spring surveys with Boothbay Depressor trawl in central Maine area.

\begin{tabular}{lll}
\hline Parameter & Inshore systematic & \multicolumn{1}{c}{ Coastal stratified random } \\
\hline Stations & 8 fixed stations & $\begin{array}{l}15 \text { stations randomly selected } \\
\text { from } 1 \text { of } 4 \text { units constituting } \\
\text { each of } 15 \text { rectangles, } 10^{\prime} \text { lat. } \\
\text { by } 10^{\prime} \text { long. }\end{array}$ \\
Type of tow & Stepped oblique & Stepped oblique \\
Tows/station & One & Two \\
Tow duration & 30 min & $7.5 \mathrm{~min}$ \\
Tow distance & $5.5 \mathrm{~km}$ & $1.75 \mathrm{~km}$ \\
Tow direction & Constant & Selected randomly \\
Depths & Bottom, mid-depth & $20 \mathrm{~m}, 10 \mathrm{~m}$, near-surface \\
near-surface & Number $/ 100 \mathrm{~m}^{3}$ & Mean number $/ 100 \mathrm{~m}^{3}$ \\
\hline
\end{tabular}

In view of the rugged bottom along the coast, sampling was not extended to depths exceeding $20 \mathrm{~m}$. To determine the possible effects of this limitation, an experiment was conducted in the spring of 1967 to examine the depth distribution of larvae (Graham and Sampson, 1982). The results indicated that the larvae tended to be concentrated shallower than $20 \mathrm{~m}$ on dull days and deeper than $20 \mathrm{~m}$ on bright days. However, the extinction of light in the upper layers varies from place to place (Graham, 1970b) and, for the larvae, a bright day in one area might not be so bright in another. The stratified-random coastal sampling design was therefore continued for monitoring larval abundance, because the randomization introduced by the sampling procedures was assumed to mitigate any systematic effects upon the mean catch of larvae per survey.

The stratified-random sampling design involved making two short $(7.5 \mathrm{~min}$ ) tows at each coastal station instead of one long tow, because the special study indicated that data from long, stepped-oblique tows tended to underestimate larval abundance at a given station, the magnitude of the underestimate decreasing as the larval population increased (Graham, MS 1980a). Stratified-random sampling with short tows was not possible at the inshore stations (Table 1) because of vessel incapabilities and the confining shorelines with their associated submerged rock ledges. Therefore, long tows were made over smoother bottom in the center of embayments and estuarine channels. At one inshore station, the estuarine channel was so variable in depth that the entire long tow was made near the surface.

In inshore waters, land masses funnel and concentrate the larvae as they move into the estuaries and embayments, and the probability of capturing larvae during their migration may be greatly different from 
that in the coastal region. In view of this and other sampling difficulties, the mean catch rates from the inshore and coastal surveys were combined to give a spring index of larval abundance rather than an absolute measure. The mean catch rate for an inshore survey was based on eight long tows and that for a corresponding coastal survey was based on 15 mean catch rates from two tows at each station. These catch rates were transformed to common logarithms $\left(\log _{10}(x+1)\right)$ for some comparisons.

\section{Additional sampling}

Additional monitoring of larval herring abundance was carried out in other areas of the coast. Spring monitoring was extended to eastern Maine in 1974 and to western Maine in 1975 (Fig. 1). Although most of the coastal waters along the Maine coast were surveyed, it was not possible to sample thoroughly the many estuaries and embayments. The inshore areas chosen for sampling were assumed to be representative, an assumption which did not prevail after the early 1970's. In addition, buoyed and anchored nets were set in Sullivan Harbor at the head of Frenchman Bay (Fig. 3) during the autumn and winter of 1973 and 1974. Two lines of nets were set at each of two locations in the channel, with nets positioned at the surface, $3 \mathrm{~m}, 10 \mathrm{~m}$ and near the bottom (12-20 $\mathrm{m}$ ) in each case, and two lines were set on the subtidal flats, each with a net at the surface and one near the bottom (3-4 m). The nets were set at dusk and retrieved at dawn. Details of the sampling procedures have been described by Graham and Joule (MS 1981).

\section{Weight and length of larvae}

Chenoweth (1970) studied the length-weight relationships and condition factors of larval herring in inshore waters of central Maine during the 1960's, when larvae entered the estuaries and embayments only in the autumn. Such regressions of weight on length and condition factors were not applicable in this study, because larvae also entered the Sheepscot River estuary in winter as well as in autumn during the 1970's. It was not possible to separate these groups to determine whether they possessed similar length-weight relationships, a requirement for the application of LeCren's (1951) condition factor. Instead, the following relationship was applied:

$$
R_{i}=\left(\bar{W}_{i}-\overline{\bar{W}}\right) / \sqrt{\left(s^{2} / N_{i}\right)}
$$

where $R_{i}=$ standardized residual weight of sample $i$ from an overnight set of gillnets,

$\bar{W}_{i}=$ mean dry weight $(g)$ of sample $i$ within a given 1-mm length interval (both units transformed to $\log 10$ ),

$\overline{\bar{W}}=$ mean weight of all samples within the same length class (both units in $\log _{10}$ ),

$$
\begin{aligned}
& s^{2}=\text { sum of the variances of all samples over all } \\
& \text { length classes, }
\end{aligned}
$$

and

$$
\begin{aligned}
& N_{i}=\text { number of larvae weighed and measured } \\
& \text { in sample } i .
\end{aligned}
$$

The sum of the variances for all length classes was used rather than the variances for each length class, because Bartlett's test (Zar, 1974) indicated that the variances for the different classes were homogeneous.

The larval herring were initially preserved in $10 \%$ formalin and subsequently measured in the laboratory as standard length (SL) from the tip of the snout to the end of the caudal peduncle.

\section{Tychoplankters}

Estimates were made of the numbers of various tychoplankters captured in the buoyed and anchored nets. These organisms are considered to be associated with the bottom, but they either ascend into the watercolumn at night or are swept up from the bottom by turbulence. Jaeger et al. (1978) have reported a reasonably complete list of tychoplankters captured in buoyed and anchored nets in the Sheepscot River

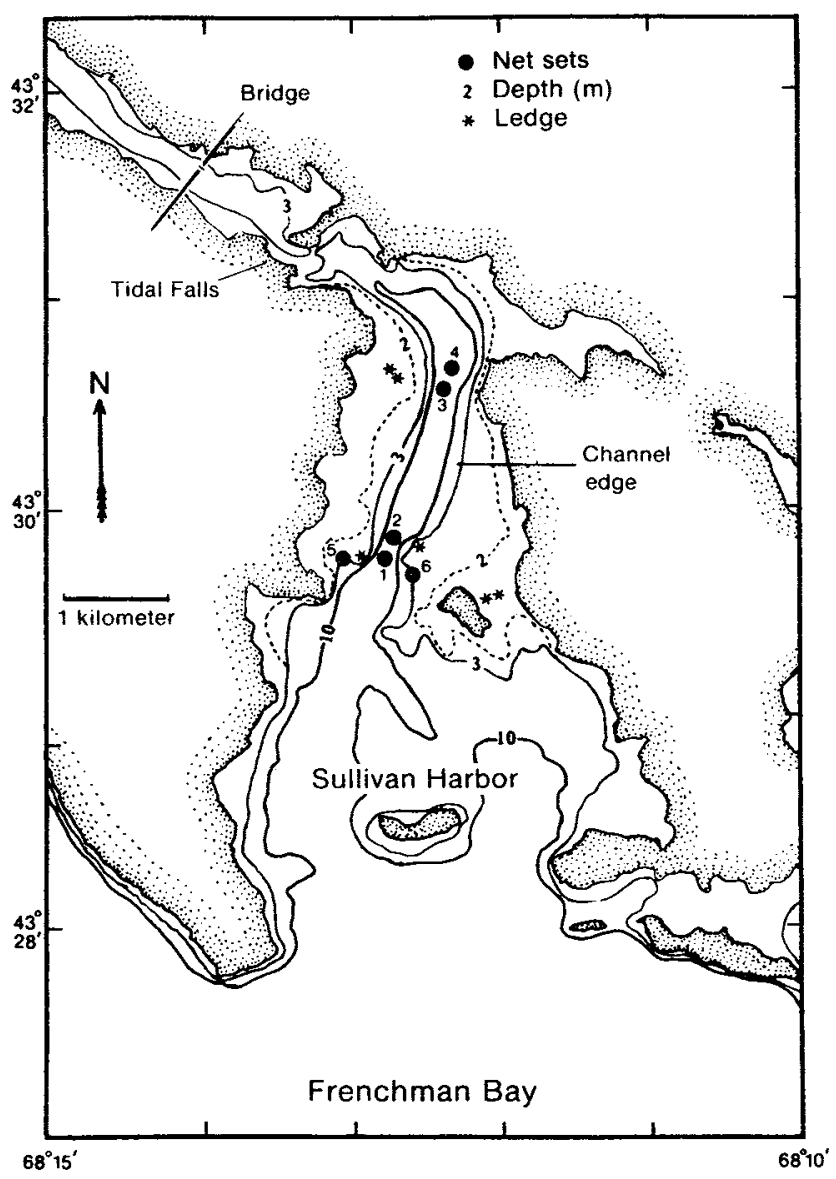

Fig. 3. Station 'ncations of buoyed and anchored nets in Sullivan Harbor for estimating larval herring abundance. 
estuary and in adjacent Montsweag Bay. Sample estimates were obtained from counts of different organisms in 10 randomly chosen squares of a large tray with a grid of 100 squares. The number of squares was increased to 20 when the sample was especially heterogeneous, and all organisms were counted when the sample contained less than 300 . Comparisons between groups of tychoplankters were made using Spearman's rank correlation coefficient.

\section{Results}

\section{Larval dispersal}

Evidence from four larval herring surveys in the autumn of 1972 indicated that hatching encompassed at least 71 days and occurred earlier in the eastern than in the western coastal waters (Fig. 4). Recentlyhatched larvae ( $<10 \mathrm{~mm} \mathrm{SL}$ ) were abundant near the headlands of Machias Bay during the first survey (2-6 September), the larval count exceeding 30 under a square meter $\left(\mathrm{m}^{2}\right)$ of sea surface. The count reached 50 during the second survey (21-24 September), and the extension of the contours westward indicated a westward drift. Also, hatching was evident for the first time in the areas south of Boothbay Harbor, off Saco Bay and near Maine's southern border. During the third survey (18-22 October), the concentration of larvae off Machias Bay was reduced and those near the approaches to Boothbay Harbor and Saco Bay were increased. The absence of small larvae during the fourth survey (6-12 November), except for small traces off Boothbay Harbor and Saco Bay, indicated little or no hatching at this time along the entire coast.

In the early September survey, the larger larvae $(10-15 \mathrm{~mm})$ were located in approximately the same area as those recently hatched (Fig. 5), but the results in late September indicated a westward drift to the offing of eastern Penobscot Bay and Boothbay Harbor. By late October, the catch contours exhibited a tongue-like distribution from east to west, with concentrations between Frenchman Bay and Machias Bay, off Penobscot Bay, and near the headlands of Boothbay Harbor and Saco Bay. When the November survey was undertaken, only a single concentration was evident near the headlands of the Boothbay Harbor area.

Because of their longer time in coastal currents, distribution of the largest larvae $(>15 \mathrm{~mm}$ ) was more extensive along the coast in the latter part of the season (Fig. 6). Few larvae exceeded $15 \mathrm{~mm}$ in length in early September, the only trace being in the eastern area off Machias Bay. However, by late September, small concentrations were also evident at the entrance to Frenchman Bay and in the offing between Penobscot Bay and Boothbay Harbor, and a considerable concentration was present off Saco Bay. During the October
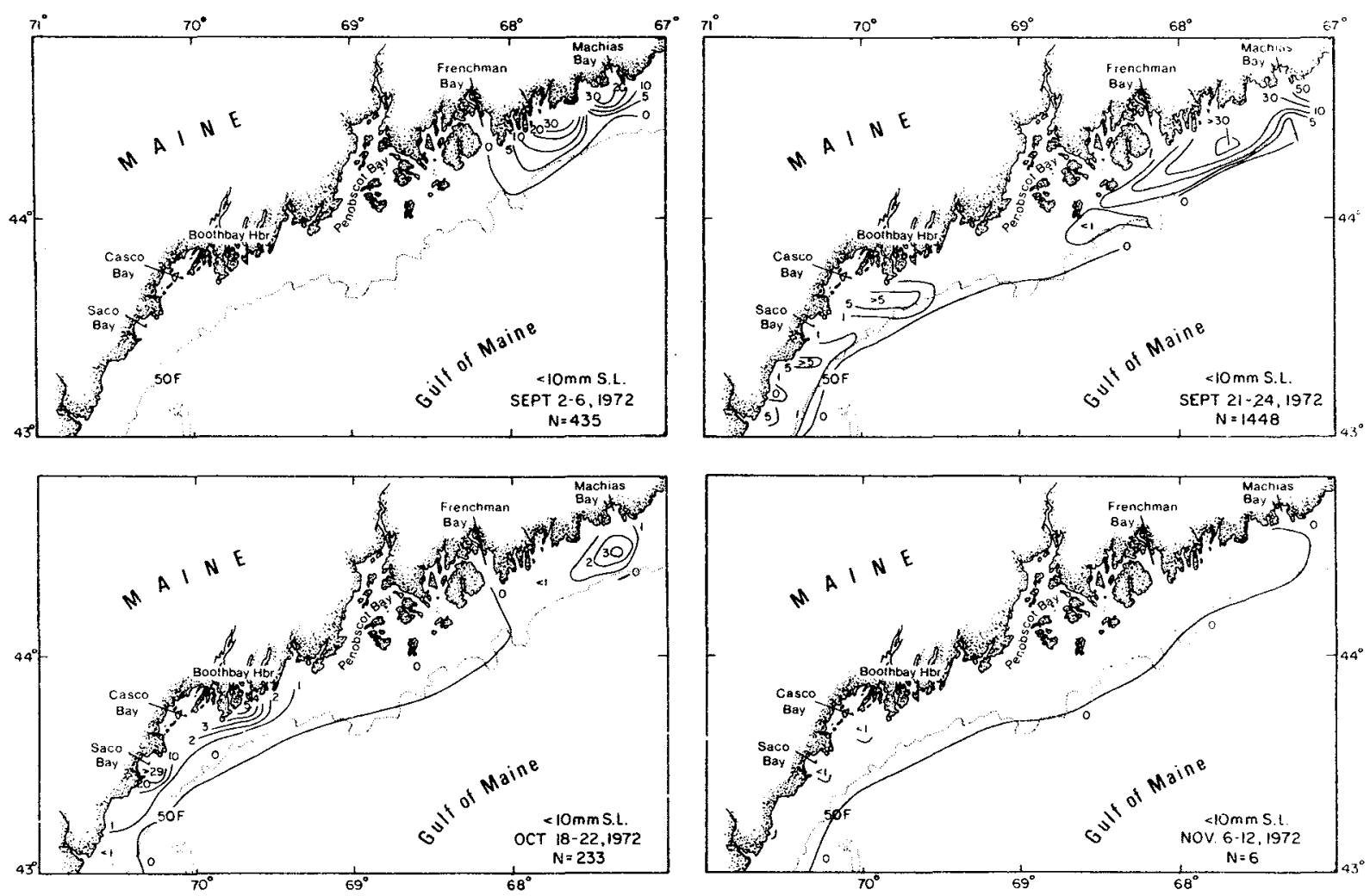

Fig. 4. Contoured distributions of larval herring $>10 \mathrm{~mm} \mathrm{SL}$ ) along the Maine coast during four autumn surveys in 1972. (The values represent numbers of larvae under a $\mathrm{m}^{2}$ of sea surface.) 

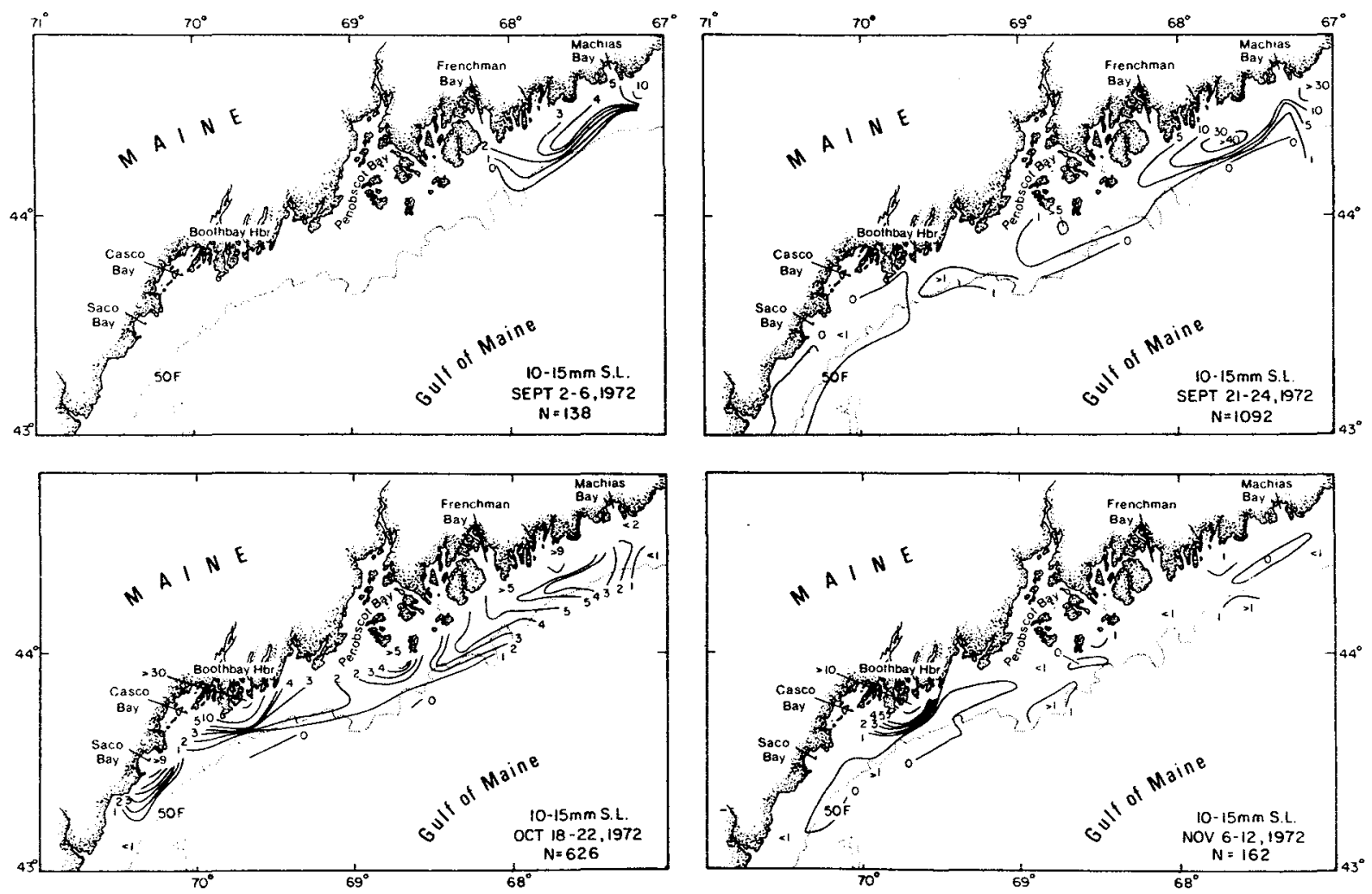

Fig. 5. Contoured distributions of larval herring (10-15 $\mathrm{mm} \mathrm{SL}$ ) along the Maine coast during four autumn surveys in 1972 . (The values represent numbers of larvae under a $\mathrm{m}^{2}$ of sea surface.)
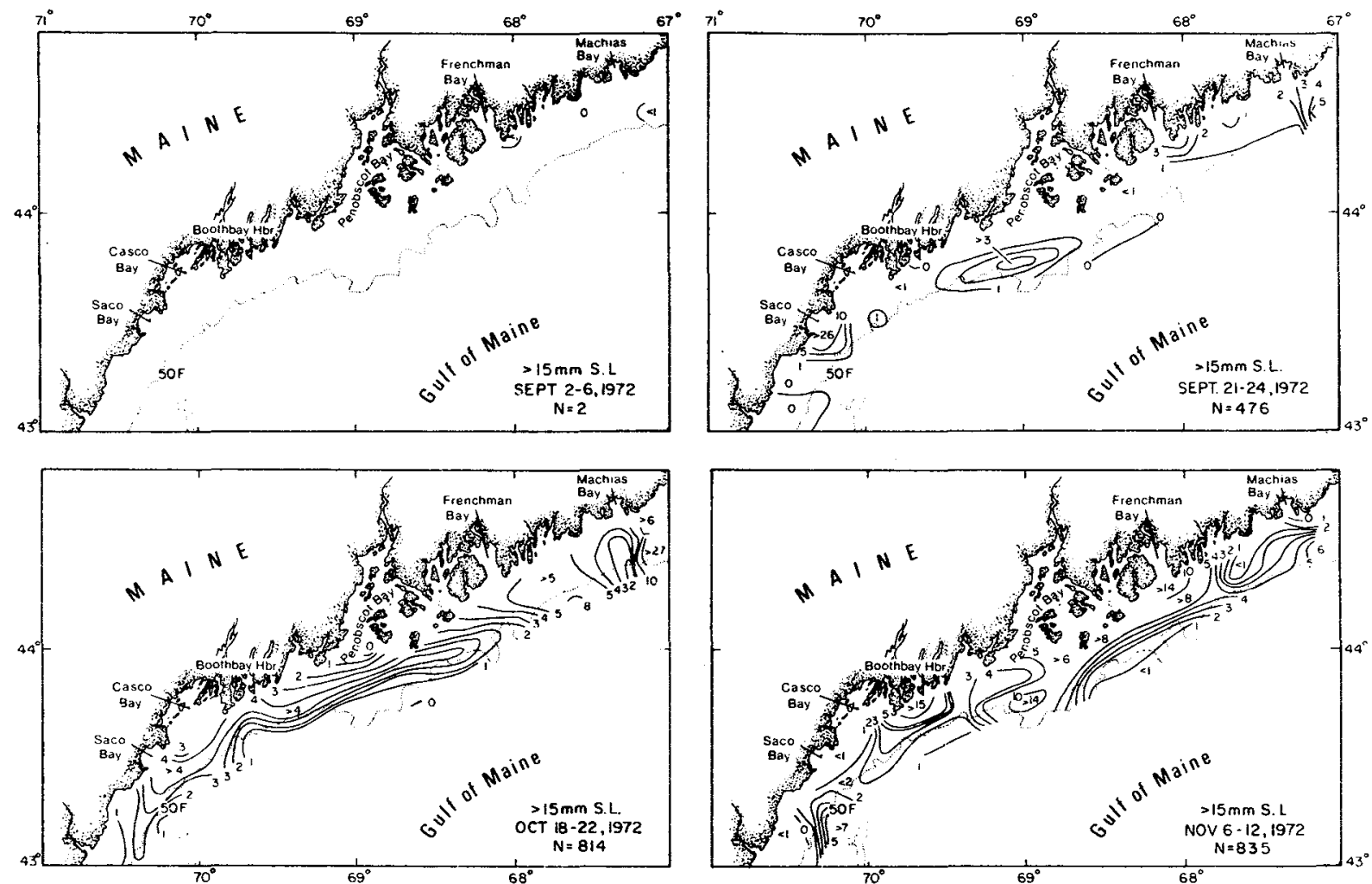

Fig. 6. Contoured distributions of larval herring $>15 \mathrm{~mm} \mathrm{SL}$ ) along the Maine coast during four autumn surveys in 1972 . (The values represent numbers of larvae under a $\mathrm{m}^{2}$ of sea surface.) 
survey, the distribution of these large larvae was extensive, with a large concentration off Machias Bay and a continuous band extending westward to Saco Bay and thence southward. During the November survey, the group of larvae off Machias Bay was still present, but there were large concentrations at the entrance to Frenchman Bay, off Penobscot Bay and near the headlands of the Boothbay Harbor area. The group of larvae present off Saco Bay may have drifted from the Saco Bay area or they may have originated from spawning on nearby Jeffreys Ledge, outlined by the dotted area just eastward of the larval concentration (Fig. 6).

Especially striking during 1972 was the tendency for larvae to be restricted to coastal waters, approximately $28 \mathrm{~km}$ seaward of the headlands, as indicated by the 0 and 1 contours of catch rates on the seaward side of the larval distributions except for a group of large larvae (>15 mm) off Machias Bay (Fig. 6). Colton and St. Onge (1974), in their atlas of larval fish distributions, showed only occasional catches of larval herring in the open Gulf of Maine during autumn, as also did Smith et al. (MS 1980). An extension of the survey area would have been necessary to determine the seaward distribution of these large larvae off Machias Bay.

Since hatching occurs earlier in eastern Maine, the movement of larvae into the estuaries and embayments begins earlier there. Graham and Davis (1971) indicated that, in the 1960's, larvae continued to enter the Boothbay Harbor area until early December, and this movement was documented by Graham et al. (1972).

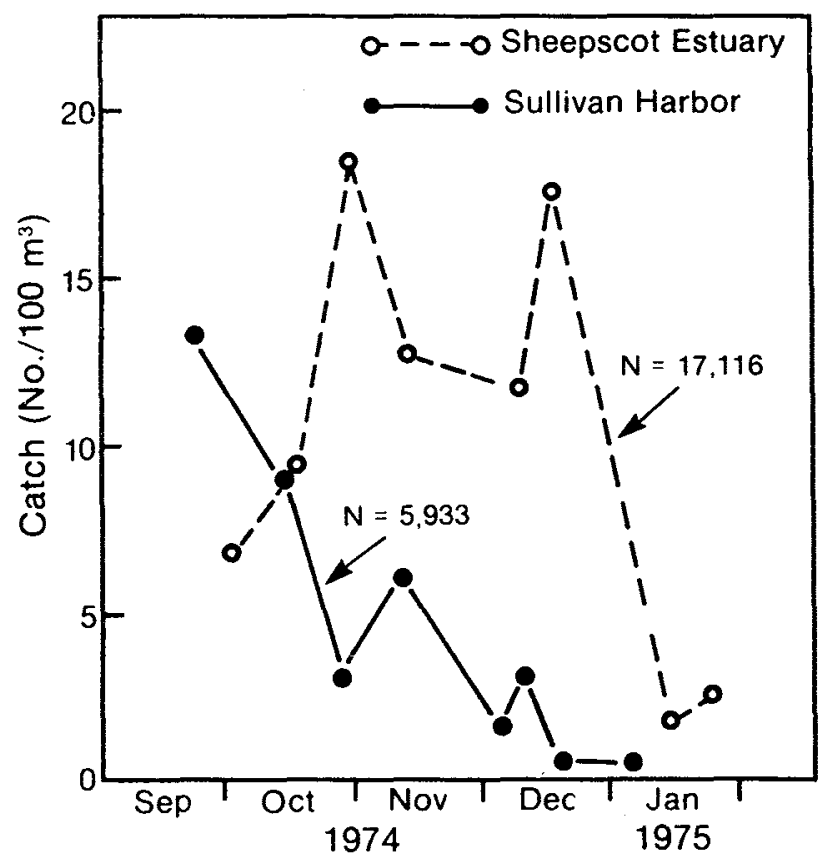

Fig. 7. Catch rates of larval herring in Sheepscot River estuary (central Maine) and Sullivan Harbor (eastern Maine) during the autumn 1974 and early winter 1975.
However, in the 1970's, the movement of larvae into the estuaries and embayments continued into the winter. This is indicated by the progression in catch rate as larvae moved into the Sheepscot River estuary of the Boothbay area and into Sullivan Harbor at the head of Frenchman Bay during late 1974 and early 1975 (Fig. 7). In Sullivan Harbor, the catch rate declined almost continuously from a peak in late September to a low in late December. In the Sheepscot River estuary, the initial peak occurred about a month later in October and this was followed by another peak in late December. This occurrence in late December 1974 heralded changes in larval movements in subsequent years.

These changes in movement of larval herring into the Sheepscot River estuary are illustrated in Fig. 8-10, which show contours of catch rates by size of larvae with time. Two examples of early data (1965 and 1966 year-classes) are presented in Fig. 8 as being typical of data for the 1964-73 period when larval catch rates

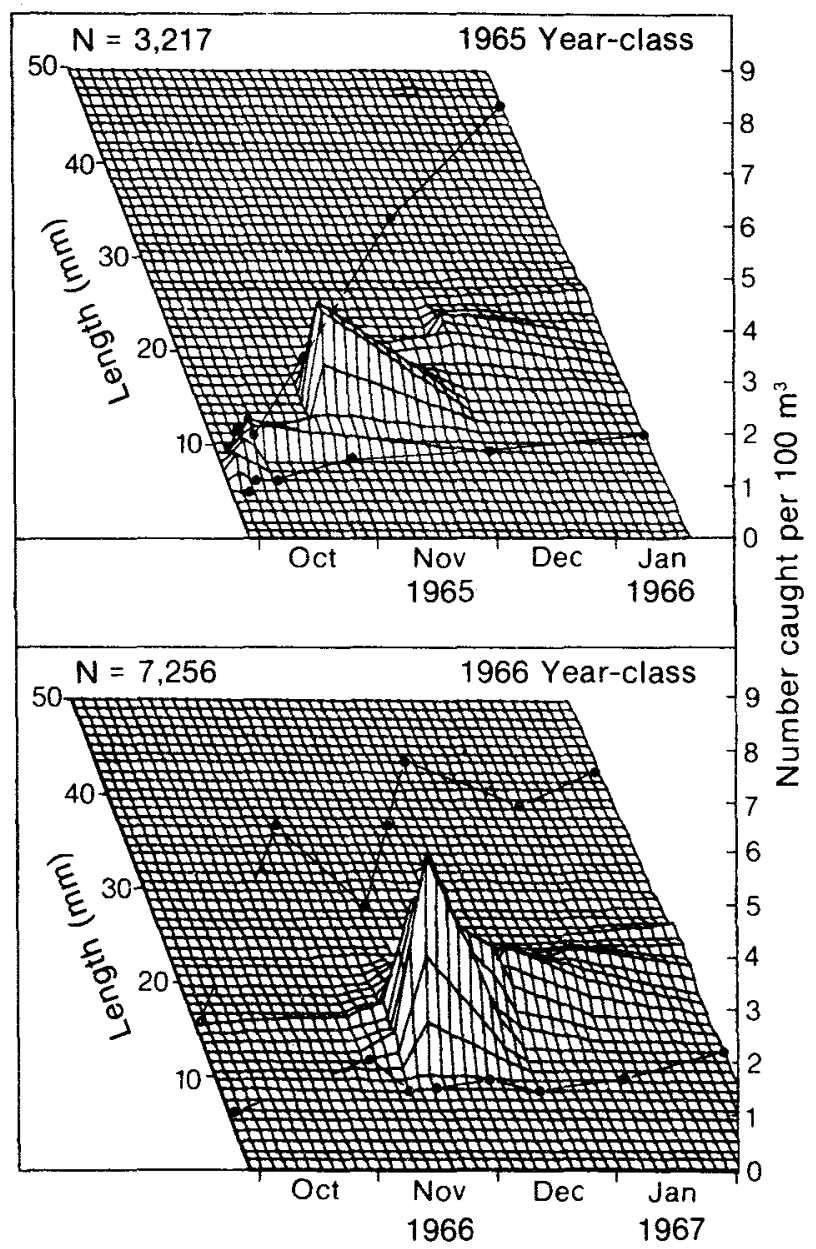

Fig. 8. Catch rates by size of the 1965 and 1966 year-classes of larvae herring in the Sheepscot River estuary during autumn and winter. (Maximum and minimum lengths are indicated by $\bullet \longrightarrow$.) 


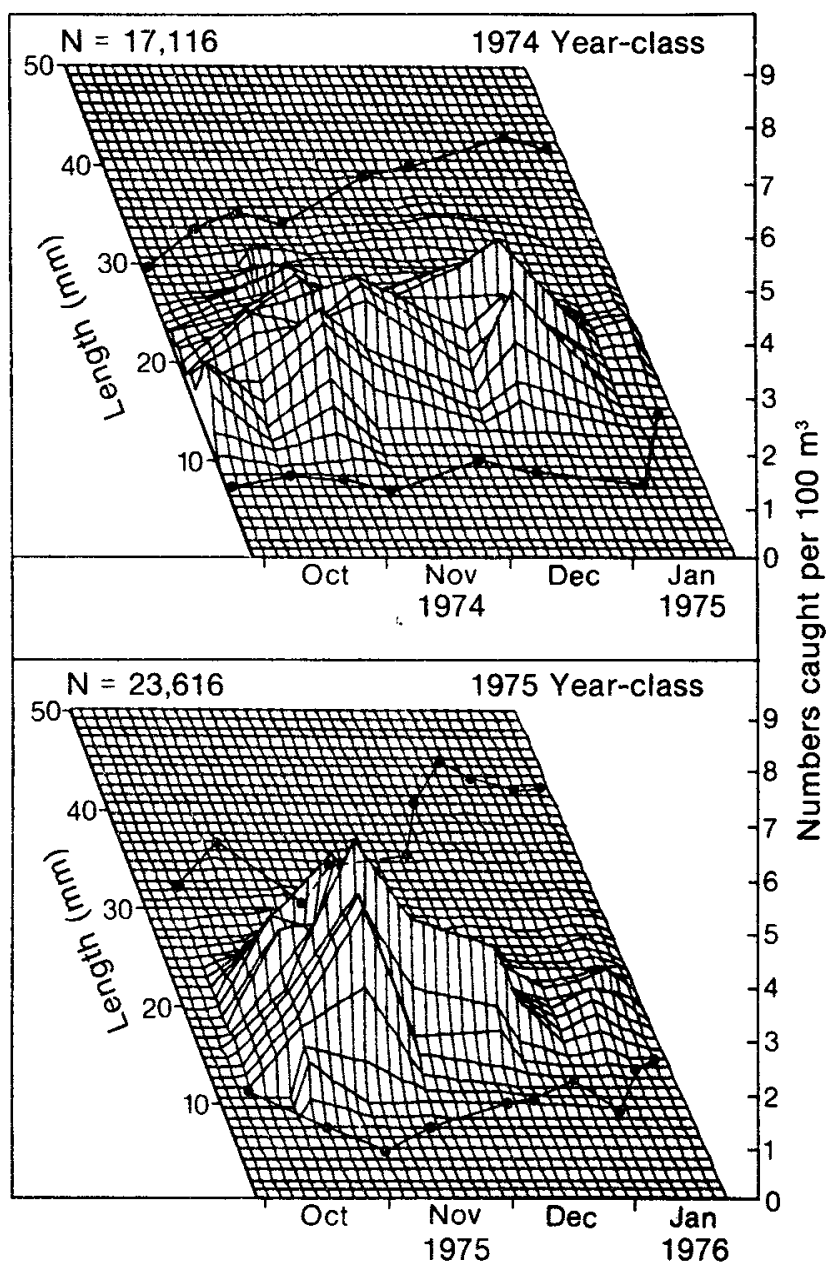

Fig. 9. Catch rates by size of the 1974 and 1975 year-classes of larval herring in the Sheepscot River estuary during autumn and winter. (Maximum and minimum lengths are indicated by $\bullet$.)

peaked in autumn and declined in winter (autumn data are not available for 1971). Five years of change (1974-1978 year-classes) are shown in Fig. 9 and 10.

For the 1965, 1966 and 1977 year-classes (Fig. 8 and 10), catches of larvae declined from an autumn peak to low values in December. However, for the 1974 and 1975 year-classes (Fig. 9), relatively small larvae entered the estuary in mid-December and January respectively. Many of these larvae were the same size as those present in the estuary 1-2 months earlier. Four successive larval groups of the 1976 year-class entered the estuary between October and February (Fig. 10), the larvae of each successive group being somewhat larger than its predecessor. Catch rates of the 1978 year-class were very low for all length groups during the autumn and winter in contrast to those of preceding years. However, a study of the otoliths of the larvae of this year-class indicated that the slight increases in the catch rate in January and February were caused by an inshore movement of larvae hatched later than

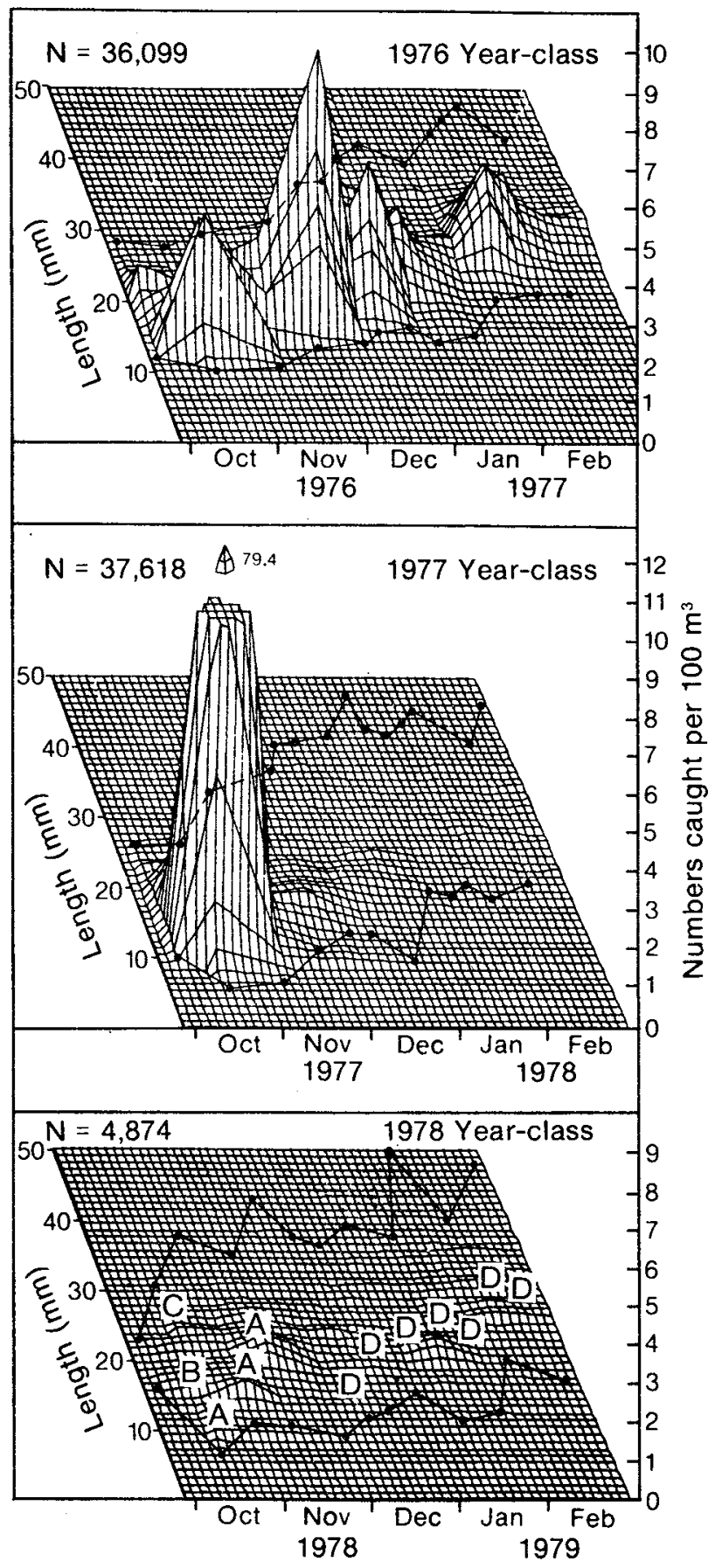

Fig. 10. Catch rates by size of the 1976,1977 and 1978 year-classes of larval herring in the Sheepscot River estuary during autumn and winter. (Maximum and minimum lengths are indicated by $\stackrel{\longrightarrow}{\longrightarrow}$

those present in November (Townsend and Graham, 1981). From length and age composition data, it was possible to indicate the occurrence of the various larval groups of the 1978 year-class (Fig. 10). Three groups ( $A, B$ and $C$ ) were present in the estuary in October but only group $A$ persisted and reached a peak in catch rate in November. In December, another group (D) 
entered the estuary and its continued recruitment caused a peak in catch rate in January which persisted into February. According to Townsend and Graham (1981), both the A and D groups experienced a cessation or slowing of growth (in length) in late January and early February. Group A cannot be traced through its model length in winter, but the reduction in growth is evident for group $D$.

\section{Winter mortality}

Winter mortality was severe for most year-classes of larval herring (Tables 2 and 3 ), exceeding $60 \%$ for all but the 1971 year-class and exceeding $80 \%$ for 7 of the 11 year-classes considered. The year-classes of 1964 , 1973 and 1977 suffered winter mortality in excess of 95\%. Estimates for the $1974-76$ and 1978 year-classes were not made because the larvae migrated into the estuary during the winter. The absence of such winter migration was a fundamental requirement of the experimental design (Graham and Davis, 1971).

\section{Spring abundance}

Both the catch rate per station and the mean catch rate per survey varied considerably for the coastal and inshore sampling areas. For stations in the central Maine sampling area (Fig. 2), catch rates exhibited large coefficients of variation (CV), which were very similar for both inshore and coastal sampling (Table 4). The average $C V$ was 1.43 with a range of $0.87-2.38$ for the inshore stations and 1.39 with a range of $0.86=2.23$ for the offshore stations. The overall index of spring abundance of larvae in the central Maine area varied more for the year-classes of the 1970's than for those of the 1960's. The lowest value in the 1960's $(0.63)$ was for the 1969 year-class, whereas lower values in the 1970's were recorded for the 1975, 1977 and 1978 yearclasses, and an especially high value (3.00) was

TABLE 2. Catch rates of herring larvae of the 1964-73 and 1977 yearclasses in buoyed and anchored nets in the Sheepscot River estuary for early winter sampiing in December and January.

\begin{tabular}{|c|c|c|c|c|c|c|}
\hline \multirow[b]{2}{*}{$\begin{array}{l}\text { Year- } \\
\text { class }\end{array}$} & \multicolumn{3}{|c|}{ First sampling } & \multicolumn{3}{|c|}{ Second sampling } \\
\hline & Date & $\begin{array}{l}\text { No. of } \\
\text { larvae }\end{array}$ & $\begin{array}{l}\text { No. per } \\
100 \mathrm{~m}^{3}\end{array}$ & Date & $\begin{array}{l}\text { No. of } \\
\text { larvae }\end{array}$ & $\begin{array}{l}\text { No. per } \\
100 \mathrm{~m}^{3} \\
\end{array}$ \\
\hline 1964 & $16 \mathrm{Dec}$ & 1,849 & 5.59 & $30 \mathrm{Dec}$ & 287 & 3.33 \\
\hline 1965 & $9 \mathrm{Dec}$ & 928 & 2.96 & $20 \mathrm{Jan}$ & 252 & 1.45 \\
\hline 1966 & $21 \mathrm{Dec}$ & 1,045 & 5.46 & $20 \mathrm{Jan}$ & 826 & 3.99 \\
\hline 1967 & $18 \mathrm{Dec}$ & 462 & 2.06 & $18 \mathrm{Jan}$ & 197 & 1.03 \\
\hline 1968 & $12 \mathrm{Dec}$ & 736 & 4.08 & 7 Jan & 468 & 2.35 \\
\hline 1969 & $15 \mathrm{Dec}$ & 96 & 0.58 & $15 \mathrm{Jan}$ & 38 & 0.21 \\
\hline 1970 & $21 \mathrm{Dec}$ & 232 & 1.95 & $18 \mathrm{Jan}$ & 149 & 0.95 \\
\hline 1971 & $16 \mathrm{Dec}$ & 157 & 0.47 & $13 \mathrm{Jan}$ & 134 & 0.42 \\
\hline 1972 & $22 \mathrm{Dec}$ & 146 & 0.49 & 21 Jan & 116 & 0.32 \\
\hline 1973 & $23 \mathrm{Dec}$ & 174 & 1.31 & $18 \mathrm{Jan}$ & 104 & 0.40 \\
\hline 1977 & $21 \mathrm{Dec}$ & 774 & 1.39 & $15 \mathrm{Jan}$ & 117 & 0.25 \\
\hline
\end{tabular}

recorded for the 1976 year-class. Because data for the inshore and coastal stations could not be integrated, due to differences in sampling procedures (Table 1), this variation was examined separately for the two types of stations by applying the Kruskal-Wallis test (Zar, 1974). Data for the 1965 year-class were omitted because the sampling period was earlier than the others and the catch rates might not be representative of the later distribution of larvae in inshore and coastal areas. The Kruskal-Wallis test indicated no significant difference for the inshore stations $\left(X^{2}=13, H_{0.05}=21\right)$, but a significant difference was indicated for the coastal stations $\left(X^{2}=50\right)$. The application of Dunn's (1964) test of multiple comparisons using rank sums to the data from the coastal stations indicated that no contiguous groups of year-classes differed from one another, although the mean rank sums for some of the yearclasses in the 1960's were not compatible with those of the 1970's.

Average indices of larval abundance for the $1974-78$ year-classes in eastern Maine $(0.56)$ and western Maine (0.65) were somewhat lower than that (1.03) for central Maine (Table 4), but the last value is greatly influenced by the anomalously high catch rate for the 1976 year-class. The 1977 year-class and to a lesser degree the 1975 year-class exhibited indices which were similar for the three areas.

A comparison of the spring abundance indices for central Maine (Table 4) with the estimates of winter mortality (Table 3 ) indicated that high winter mortality was followed by low abundance of larval herring in the spring. The early winter mortality estimates per tidal phase were based on sampling periods which ranged from 53 to 161 tidal phases, the average being 107. For simplicity, 100 tidal phases were used as the time unit for comparing early winter mortality estimates with

TABLE 3. Estimates of instantaneous mortality in winter for the 1964-73 and 1977 year-classes of larval herring based on the data in Table 2. (A tidal phase is about $6.2 \mathrm{hr}$ and winter mortality is computed over 3 months or 348 tidal phases.)

\begin{tabular}{lccccc}
\hline \hline Year- & $\begin{array}{c}\text { Sampling } \\
\text { period } \\
\text { mortality }\end{array}$ & $\begin{array}{c}\text { No. of } \\
\text { tidal } \\
\text { phases }\end{array}$ & $\begin{array}{c}\text { Mortality } \\
\text { per tidal } \\
\text { phase }\end{array}$ & $\begin{array}{c}\text { Winter } \\
\text { mortality } \\
\text { rate }\end{array}$ & $\begin{array}{c}\text { Winter } \\
\text { mortality } \\
(\%)\end{array}$ \\
\hline 1964 & 0.518 & 53 & 0.00977 & 3.40 & 96.7 \\
1965 & 0.714 & 161 & 0.00444 & 1.54 & 78.6 \\
1966 & 0.314 & 113 & 0.00278 & 0.97 & 62.1 \\
1967 & 0.693 & 119 & 0.00582 & 2.02 & 86.7 \\
1968 & 0.552 & 99 & 0.00557 & 1.94 & 85.6 \\
1969 & 1.016 & 119 & 0.00854 & 2.97 & 94.9 \\
1970 & 0.719 & 105 & 0.00685 & 2.38 & 90.7 \\
1971 & 0.112 & 106 & 0.00106 & 0.37 & 30.9 \\
1972 & 0.426 & 114 & 0.00374 & 1.30 & 72.7 \\
1973 & 1.186 & 100 & 0.01186 & 4.13 & 98.4 \\
1977 & 1.716 & 96 & 0.01788 & 6.22 & 99.8 \\
\hline
\end{tabular}


TABLE 4. Spring catches of larval herring and catch rates from coastal and inshore sampling along the Maine coast. (The index of relative abundance is the sum of the coastal and inshore catch rates.)

\begin{tabular}{|c|c|c|c|c|c|c|c|}
\hline \multirow{2}{*}{$\begin{array}{l}\text { Year- } \\
\text { class }\end{array}$} & \multirow{2}{*}{$\begin{array}{l}\text { Following year } \\
\text { sampling period }\end{array}$} & \multicolumn{3}{|c|}{ Number of larvae } & \multicolumn{3}{|c|}{ Catch per $100 \mathrm{~m}^{3}$} \\
\hline & & Coastai & Inshore & Total & Coastal & Inshore & Index \\
\hline \multicolumn{8}{|c|}{ Central Maine } \\
\hline 1965 & 9-22 Mar & 603 & 68 & 671 & 0.63 & 0.20 & 0.83 \\
\hline 1966 & $28 \mathrm{Mar}-6 \mathrm{Apr}$ & 284 & 136 & 420 & 0.49 & 0.60 & 1.09 \\
\hline 1967 & 3-12 Apr & 120 & 193 & 313 & 0.22 & 0.68 & 0.90 \\
\hline 1968 & 15-22 Apr & 160 & 208 & 368 & 0.31 & 0.73 & 1.04 \\
\hline 1969 & 7-13 Apr & 94 & 77 & 171 & 0.20 & 0.43 & 0.63 \\
\hline 1970 & $30 \mathrm{Mar}-12 \mathrm{Apr}$ & 90 & 258 & 348 & 0.25 & 0.85 & 1.10 \\
\hline 1971 & $30 \mathrm{Mar}-12 \mathrm{Apr}$ & 33 & 482 & 515 & 0.04 & 1.16 & 1.20 \\
\hline 1972 & 16-22 Apr & 328 & 130 & 458 & 0.84 & 0.30 & 1.14 \\
\hline 1973 & 11-26 Apr & 120 & 171 & 291 & 0.32 & 0.40 & 0.72 \\
\hline 1974 & 10-16 Apr & 17 & 362 & 379 & 0.04 & 0.84 & 0.88 \\
\hline 1975 & 7-13 Apr & 77 & 110 & 187 & 0.20 & 0.25 & 0.45 \\
\hline 1976 & $11-19 \mathrm{Apr}$ & 107 & 1,169 & 1,176 & 0.28 & 2.72 & 3.00 \\
\hline 1977 & $29 \mathrm{Mar}-10 \mathrm{Apr}$ & 33 & 159 & 192 & 0.08 & 0.37 & 0.45 \\
\hline 1978 & 11-16 Apr & 14 & 44 & 58 & 0.08 & 0.29 & 0.37 \\
\hline \multicolumn{8}{|c|}{ Eastern Maine } \\
\hline 1973 & 3-8 Apr & 56 & 41 & 97 & 0.13 & 0.11 & 0.24 \\
\hline 1974 & 2-10 Apr & 102 & 152 & 254 & 0.25 & 0.40 & 0.65 \\
\hline 1975 & 26-30 Mar & 81 & 19 & 100 & 0.25 & 0.09 & 0.34 \\
\hline 1976 & $28 \mathrm{Mar}-2 \mathrm{Apr}$ & 39 & 97 & 136 & 0.10 & 0.26 & 0.36 \\
\hline 1977 & 28-30 Mar & 23 & 23 & 46 & 0.06 & 0.42 & 0.48 \\
\hline 1978 & $27 \mathrm{Mar}-4 \mathrm{Apr}$ & 128 & 112 & 240 & 0.68 & 0.30 & 0.98 \\
\hline \multicolumn{8}{|c|}{ Western Maine } \\
\hline 1974 & 11-18 Apr & 57 & 98 & 155 & 0.42 & 0.46 & 0.88 \\
\hline 1975 & 14-15 Apr & 31 & 33 & 64 & 0.23 & 0.09 & 0.32 \\
\hline 1976 & 19-20 Apr & 60 & 155 & 215 & 0.32 & 0.48 & 0.80 \\
\hline 1977 & 10-12 Apr & 32 & 112 & 144 & 0.17 & 0.30 & 0.47 \\
\hline 1978 & 16-19 Apr & 45 & 48 & 93 & 0.47 & 0.32 & 0.79 \\
\hline
\end{tabular}

spring abundance of larvae (Fig. 11). Significantly high correlations are indicated whether the spring abundance index is based on the catch rates given in the last column of Table 4 or on the means of logarithmically transformed catches. Although the mortality estimates were made in the early part of the winter (Table 2), the good agreement shown in Fig. 11 indicates that larval mortality may have remained relatively constant during the remainder of the winter period. For this reason, the calculation of mortality for the winter season seems practicable.

\section{Larval weights and catch rates}

The study of residual larval weights in the autumn and winter of 1976/77, 1977/78 and 1978/79 provided the basis for their comparison with trends in catch rates (Fig. 12) for the 1976, 1977 and 1978 year-classes of larval herring. Relative variation in weight and catch rate for the 1976 year-class had a similar pattern except on two occasions (Fig. 12A). In early October 1976 and late January 1977, positive deviations in weight paralleled negative deviations in catch rate. in the first case, the sample contained relatively large larvae which accounted for the large positive deviation. For the 1977 year-class (Fig. 12B), deviations in weight fluctuated greatly from one sampling date to the next but were mainly positive from late November to late January after which there was a rapid decline to a record negative value in late February. Except for the early autumn peak, the trend in catch rate varied little throughout the period and bore little resemblance to the trend in weight deviations.

For the 1978 year-class (Fig. 12C), there was some similarity to the 1976 year-class despite the low numbers of larvae caught in 1978. In October 1978, groups B and C (Fig. 10) consisted of large larvae and yielded a large positive deviation in weight, as in early October 1976, followed by a decline in mean weight as they declined in abundance. The positive deviation in weight in November coincided with a peak catch representing the dominance of group A (Fig. 10). As group $A$ and the overall catch rate declined, a large negative deviation in weight occurred in December. However, as occurred in January 1977 (Fig. 12A), there was a large positive deviation in weight in January 1979 just prior to the peak catch rate in February (Fig. 12C) caused by the influx of group D (Fig. 10). In all 3 years, the residual mean weights declined sharply in February.

\section{Predators and competitors}

Predatory fish captured in the buoyed and anchored nets at night were dispersed over the area 


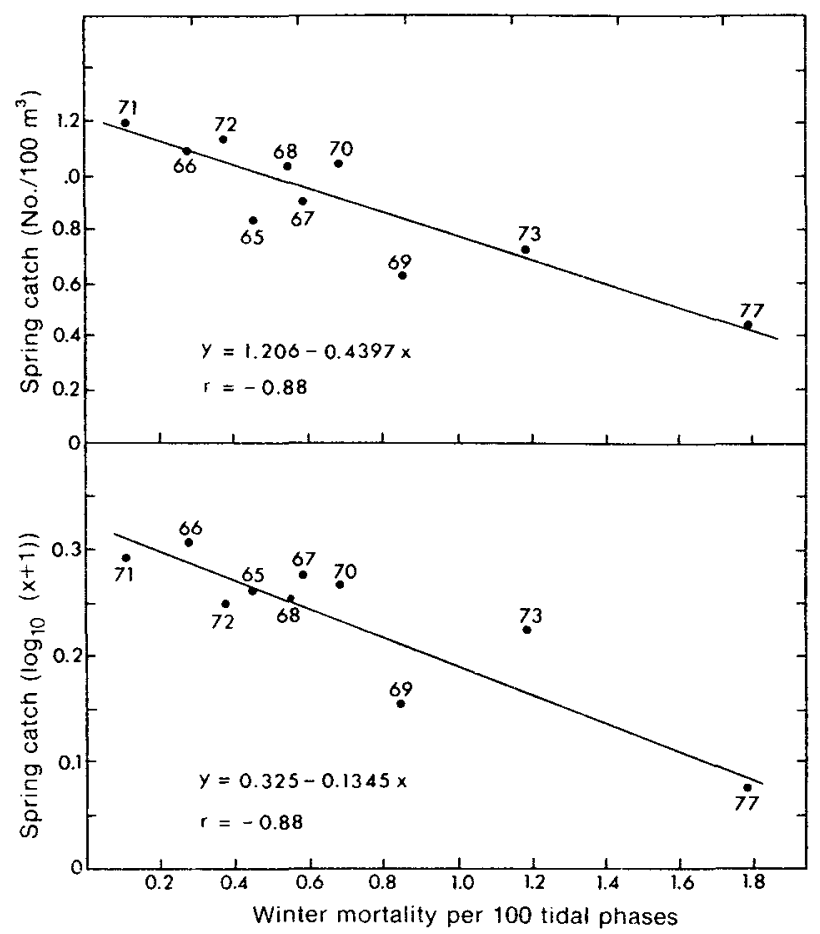

Fig. 11. Relationships between estimates of winter mortality of larvae in Sheepscot River estuary and indices of spring abundance in the central Maine coastal area, 1965-73 and 1977. (No winter mortality estimates are available for 1974-76.)

sampled and occurred at all depths in the Sheepscot River estuary in the autumn and winter seasons of $1973 / 74$ to $1977 / 78$ and in Sullivan Harbor in 1973/74 (Table 5). Some demersal species were caught, the most unusual occurrence being a small skate, Raja sp., captured in a surface net in the Sheepscot River estuary. The most abundant species was the 3-spined stickleback, Gasterosteus aculeatus, in three specimens of which were found larval fishes, one being a herring larva. A large herring larva ( $43 \mathrm{~mm} \mathrm{SL}$ ) was also found in the stomach of a sculpin ( $84 \mathrm{~mm}$ total length). Of 171 fish stomachs examined, $40 \%$ contained a variety of fresh and partially digested prey organisms belonging largely to the following invertebrate groups: Sagittae (arrow worms), Copepoda, Amphipoda, Natantia (shrimps), and isopoda. During the winter of 1977, comb jellies (Ctenophora) were abundant in the Sheepscot River estuary and probably preyed upon larval herring among other organisms. The examination of comb jellies for consumed prey during the processing of net catches revealed one with a herring larva $(27 \mathrm{~mm} \mathrm{SL})$ and another containing arrow worms, copepods and shrimp.

At night, tychoplankters usually ascend from their habitat into the water column where they either compete with or perhaps prey upon herring larvae. Their status as competitors is considered here in the sense that they compete spatially with larval herring in the pelagic environment. The tychoplankters were abundant and those captured in the nets at night were as

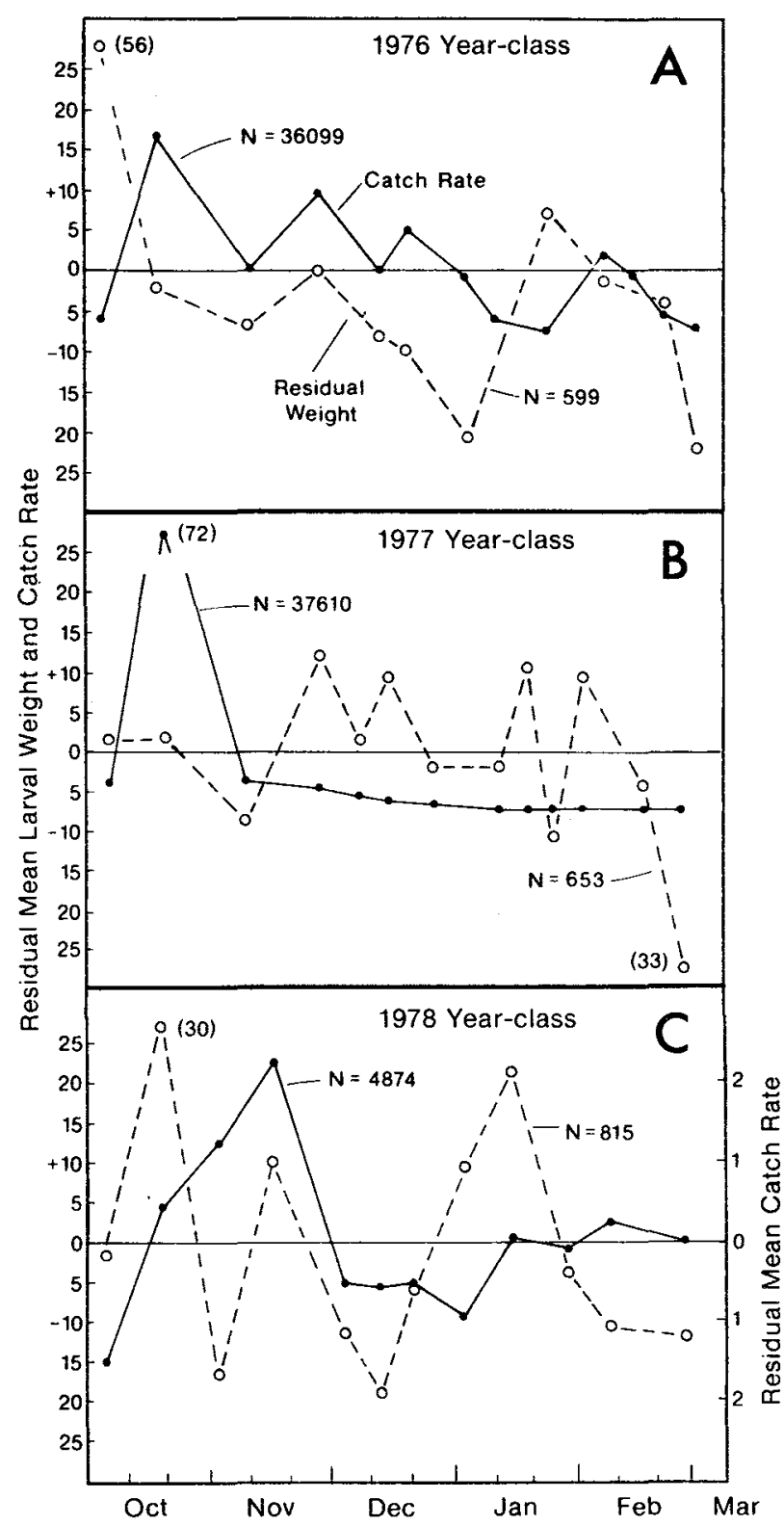

Fig. 12. Comparisons of deviations from mean weight (standardized residuals) with deviations from mean catch rate for the 1976 , 1977 and 1978 year-classes of larval herring during autumn and winter.

large as the larval herring and sometimes larger. For example, during the autumn and winter of $1973 / 74$ to $1977 / 78$, bloodworms, Glycera dibranchiata, were captured at all depths in Sullivan Harbor, their size ranging from 0.02 to $1.47 \mathrm{~g}$ (Graham and Creaser, 1978), and small mussels, maximum shell diameter of $2-4 \mathrm{~mm}$. were also abundant in the samples.

Groups of tychoplankters were usually more abundant in the nets than larval herring (Table 6). Using Spearman's rank correlation coefficient as a measure of association between the various ungrouped distributions of captured organisms resulted in significant associations between larval 
TABLE 5. Common juvenile and small adult fishes captured coincidently with herring larvae in buoyed and anchored nets in Sullivan Harbor and Sheepscot River estuary, and qualitative analysis of stomachs examined.

\begin{tabular}{|c|c|c|c|c|c|c|c|c|}
\hline \multirow[b]{2}{*}{ Common name } & \multirow[b]{2}{*}{ Scientific name } & \multirow[b]{2}{*}{$\begin{array}{c}\text { Number } \\
\text { caught }\end{array}$} & \multirow{2}{*}{$\begin{array}{c}\text { Length } \\
\text { range } \\
(\mathrm{mm})\end{array}$} & \multicolumn{4}{|c|}{ Qualitative stomach contents } & \multirow{2}{*}{$\begin{array}{c}\text { Fish } \\
\text { larvae } \\
\text { found }\end{array}$} \\
\hline & & & & $\begin{array}{l}\text { Number } \\
\text { exam. }\end{array}$ & $\begin{array}{l}\text { Fresh } \\
\text { food }\end{array}$ & $\begin{array}{l}\text { Digested } \\
\text { food }\end{array}$ & Empty & \\
\hline 3-spined stickleback & Gasterosteus aculeatus & 119 & $26-61$ & 81 & 13 & 19 & 49 & $3^{a}$ \\
\hline American eel & Anguilla rostrata & 79 & $36-55$ & \multicolumn{5}{|c|}{ None examined } \\
\hline Rock gunnel & Pholis gunnellus & 31 & $33-86$ & 24 & 2 & 5 & 17 & 0 \\
\hline Righteye flounders & Pleuronectidae & 30 & $34-125$ & 25 & 2 & 5 & 18 & 0 \\
\hline Northern pipefish & Syngnathus fuscus & 29 & $25-220$ & 8 & - & - & 8 & 0 \\
\hline Sculpins & Cottidae & 17 & $32-88$ & 12 & 6 & 2 & 4 & $1^{\mathrm{b}}$ \\
\hline Ocean pout & Macrozoarces americanus & 16 & $31-56$ & \multicolumn{5}{|c|}{ None examined } \\
\hline Atlantic herring & Clupea harengus & 7 & $54-90$ & 7 & 2 & 5 & - & 0 \\
\hline Lumpfish & Cyclopterus lumpus & 8 & $27-47$ & 8 & 4 & - & 4 & 0 \\
\hline Others (6 species) & - & 16 & $35-194$ & 6 & 1 & 2 & 3 & 0 \\
\hline Total & & 352 & $25-220$ & 171 & 30 & 38 & 103 & 4 \\
\hline
\end{tabular}

a 1 herring larva and 2 unidentified.

- 1 herring larva.

TABLE 6. Summary of catches of larval herring and tychoplankton in overnight sets of buoyed and anchored nets in Sheepscot River estuary on 18-19 October 1973 and in Sullivan Harbor on 23 September and 14 October 1974.

\begin{tabular}{cccc}
\hline $\begin{array}{c}\text { Depth } \\
(\mathrm{m})\end{array}$ & $\begin{array}{c}\text { Herring } \\
\text { larvae }\end{array}$ & Cumacea Amphipoda Mytilidae $^{\mathrm{b}}$ & Mysidacea \\
\hline
\end{tabular}

\begin{tabular}{|c|c|c|c|c|c|}
\hline \multicolumn{6}{|c|}{ Sheepscol River (ebb tide, 18 Oct 1973) } \\
\hline 0 & 1,254 & 1,884 & 930 & 420 & 570 \\
\hline 10 & 76 & 771 & 520 & 863 & 177 \\
\hline 15 & 39 & 670 & 407 & 498 & 236 \\
\hline 20 & 8 & 112 & 369 & 243 & 433 \\
\hline Total & 1,377 & 3,437 & 2,234 & 2,024 & 1,516 \\
\hline $\mathrm{N} / 100 \mathrm{~m}^{3}$ & 16.2 & 40.3 & 26.2 & 23.7 & 17.8 \\
\hline \multicolumn{6}{|c|}{ Sheepscol River (flood tide, 19 Oct 1973) } \\
\hline 0 & 329 & 199 & 56 & 205 & 91 \\
\hline 10 & 159 & 555 & 307 & 487 & 86 \\
\hline 15 & 888 & 1,515 & 935 & 548 & 662 \\
\hline 20 & 577 & 604 & 373 & 216 & 315 \\
\hline Total & 1,953 & 2,873 & 1,671 & 1,456 & 1,154 \\
\hline $\mathrm{N} / 100 \mathrm{~m}^{3}$ & 21.3 & 31.4 & 18.2 & 15.9 & 12.6 \\
\hline \multicolumn{6}{|c|}{ Sullivan Harbor (23 Sep 1974) } \\
\hline 0 & 682 & 1,485 & 780 & 319 & 2,142 \\
\hline 3 & 555 & 1,265 & 880 & 385 & 2,125 \\
\hline 10 & 842 & 2,000 & 855 & 800 & 1,440 \\
\hline 12 & - & 140 & 675 & 90 & 260 \\
\hline 20 & 345 & 760 & 310 & 110 & 690 \\
\hline Total & 2,424 & 5,650 & 3,500 & 1,700 & 6,657 \\
\hline $\mathrm{N} / 100 \mathrm{~m}^{3}$ & 13.5 & 31.4 & 19.4 & 9.5 & 37.0 \\
\hline \multicolumn{6}{|c|}{ Sullivan Harbor (14 Oct 1974) } \\
\hline 0 & 434 & 1,096 & 1,878 & 513 & 3,025 \\
\hline 3 & 391 & 1,445 & 1,055 & 610 & 3,305 \\
\hline 10 & 758 & 1,062 & 1,665 & 684 & 2,169 \\
\hline 12 & 1 & 75 & 1,409 & 264 & 98 \\
\hline 20 & 70 & 224 & 670 & 414 & 669 \\
\hline Total & 1,654 & 3,902 & 6,677 & 2,485 & 9,266 \\
\hline $\mathrm{N} / 100 \mathrm{~m}^{3}$ & 8.5 & 20.0 & 34.2 & 12.7 & 47.5 \\
\hline
\end{tabular}

TABLE 7. Spearman rank correlation coefficients for comparison of ungrouped distributions of larval herring and tychoplankton groups captured in buoyed and anchored nets during autumn in Sheepscot River estuary and Sullivan Harbor. $(\mathrm{H}=$ Herring, $\mathrm{C}=$ Cumacea, $\mathrm{A}=$ Amphipoda, $\mathrm{N}=$ Natantia, $B=$ Mytilidae, and $M=$ Mysidacea. Asterisks denote levels of significance.)

\begin{tabular}{|c|c|c|c|c|c|}
\hline \multicolumn{3}{|c|}{ Sheepscot River estuary, 1973} & \multicolumn{3}{|c|}{ Sullivan Harbor, 1974} \\
\hline Test & $\begin{array}{l}\text { Ebb tide } \\
\text { (18 Oct) }\end{array}$ & $\begin{array}{l}\text { Flood tide } \\
(19 \text { Oct) }\end{array}$ & Test & $\begin{array}{l}\text { Overnight } \\
\text { (23 Sep) }\end{array}$ & $\begin{array}{l}\text { Overnight } \\
\text { (14 Oct) }\end{array}$ \\
\hline $\mathrm{H} \times \mathrm{C}$ & $0.70^{\star *}$ & 0.48 & $\mathrm{H} \times \mathrm{C}$ & $0.61^{* *}$ & $0.54^{*}$ \\
\hline $\mathrm{H} \times \mathrm{A}$ & $0.58^{*}$ & 0.08 & $H \times A$ & -0.24 & 0.01 \\
\hline$H \times N$ & 0.34 & $0.55^{\star}$ & $\mathrm{H} \times \mathrm{B}$ & $0.61^{* *}$ & 0.21 \\
\hline $\mathrm{H} \times \mathrm{M}$ & 0.33 & 0.39 & $\mathrm{H} \times \mathrm{M}$ & 0.28 & $0.57^{\star}$ \\
\hline$C \times A$ & $0.77^{\star \star}$ & $0.82^{* \star}$ & $\mathrm{C} \times \mathrm{A}$ & 0.11 & $0.52^{\star}$ \\
\hline $\mathrm{C} \times \mathrm{N}$ & $0.59^{*}$ & 0.44 & $\mathrm{C} \times \mathrm{B}$ & $0.53^{*}$ & $0.62^{*}$ \\
\hline $\mathrm{C} \times \mathrm{M}$ & 0.20 & $0.63^{*}$ & $C \times M$ & 0.44 & $0.86^{\star \star}$ \\
\hline$A \times N$ & 0.44 & 0.36 & $A \times B$ & -0.02 & $0.71^{* *}$ \\
\hline$A \times M$ & 0.28 & $0.68^{* *}$ & $A \times M$ & 0.00 & 0.34 \\
\hline$N \times M$ & 0.16 & 0.40 & $B \times M$ & $0.85^{* *}$ & $0.50^{*}$ \\
\hline$P_{0.05}$ & 0.52 & 0.50 & & 0.46 & 0.49 \\
\hline$P_{0.01}$ & 0.65 & 0.64 & & 0.58 & 0.62 \\
\hline
\end{tabular}

herring and tychoplankters in 7 of 16 comparisons (Table 7) and between different tychoplankters in 12 of the remaining 24 comparisons. The most consistent result of the analysis was the significant association of Cumacea with other groups in 11 of the 16 comparisons involving Cumacea. In the Sheepscot River estuary, significant associations between herring larvae and tychoplankters (Cumacea and Amphipoda) on the ebb tide but not on the flood tide during the night of $18 / 19$ October, indicated that comparison of overnight sets encompassing both tidal phases, as on the nights of 23/24 September and 14/15 October in Sullivan Harbor, may not necessarily represent the results from both tidal phases. 
The structure of aggregations of larval herring and their transport by currents in the autumn is known to a degree (Graham, 1972a), but the factors affecting the ascent of tychoplankton into the water column or their introduction by turbulence, as in the case of the mussels (Mytilidae), are probably very complex. Tychoplankton remain abundant in winter when larval herring are no longer aggregated and hence not involved in the competition.

\section{Larval and juvenile herring}

In this section, the indices of larval abundance are compared with the harvests of juvenile herring in the Maine fishery, under the assumption that the commercial harvest represents a valid index of juvenile abundance. Such an assumption appears justified for the 1960 's and perhaps for the early 1970's. Anthony (MS 1972) noted that an adjusted index of juvenile abundance corresponds closely to the total catch along the Maine coast by fixed gears (stop seines and weirs). The fishery is influenced to an unknown degree by the availability of herring to the fixed gear, and, although 2-year-old herring are the mainstay of the fishery, the combined catches of 1-, 2- and 3-year-olds are also considered in an attempt to reduce the effects of availability (Fig. 13).

Agreements between larval abundance indices and the harvest of juveniles were obtained for the earlier year-classes (1964-73). There was a significant correlation between the larval catch rates in December

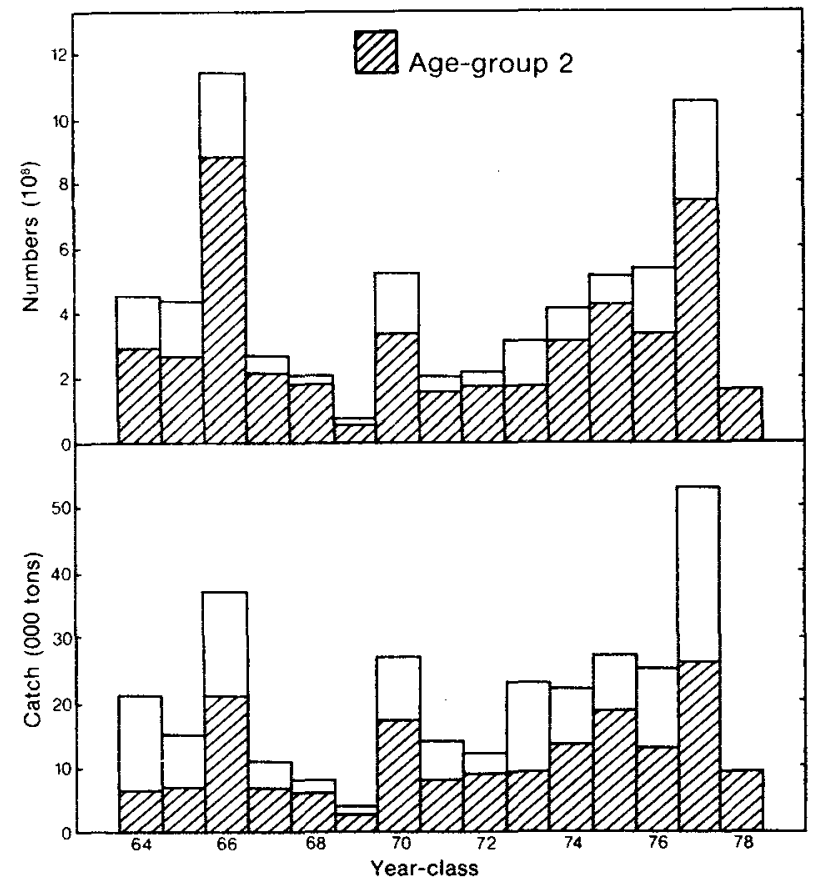

Fig. 13. Catches by year-class of juvenile herring (age-groups $1-3$ ) in number and weight in the Maine fishery during the 1965-80 period. and the numbers of 2-year-old juvenile herring (Fig. $14 \mathrm{~A})$. Correlation with the harvest of juveniles was improved when the December catch rates were multiplied by winter larval survival rates (Table 8 ) to derive an index of the effect of mortality on the initial standing crop (Fig. 14B). However, the statistical significance depended heavily on the index value for the 1966 yearclass. A high correlation was also evident between the harvest of juveniles and the spring catch rate of larvae as they approached metamorphosis into their juvenile form (Fig. 14C). Similar significant ( $P>0.05$ ) correlations were obtained when the combined harvests of 1-, 2- and 3-year-old juveniles were considered.

Disagreements between the harvests and larval abundance indices were evident for later year-classes. The very high spring larval catch of the 1976 year-class

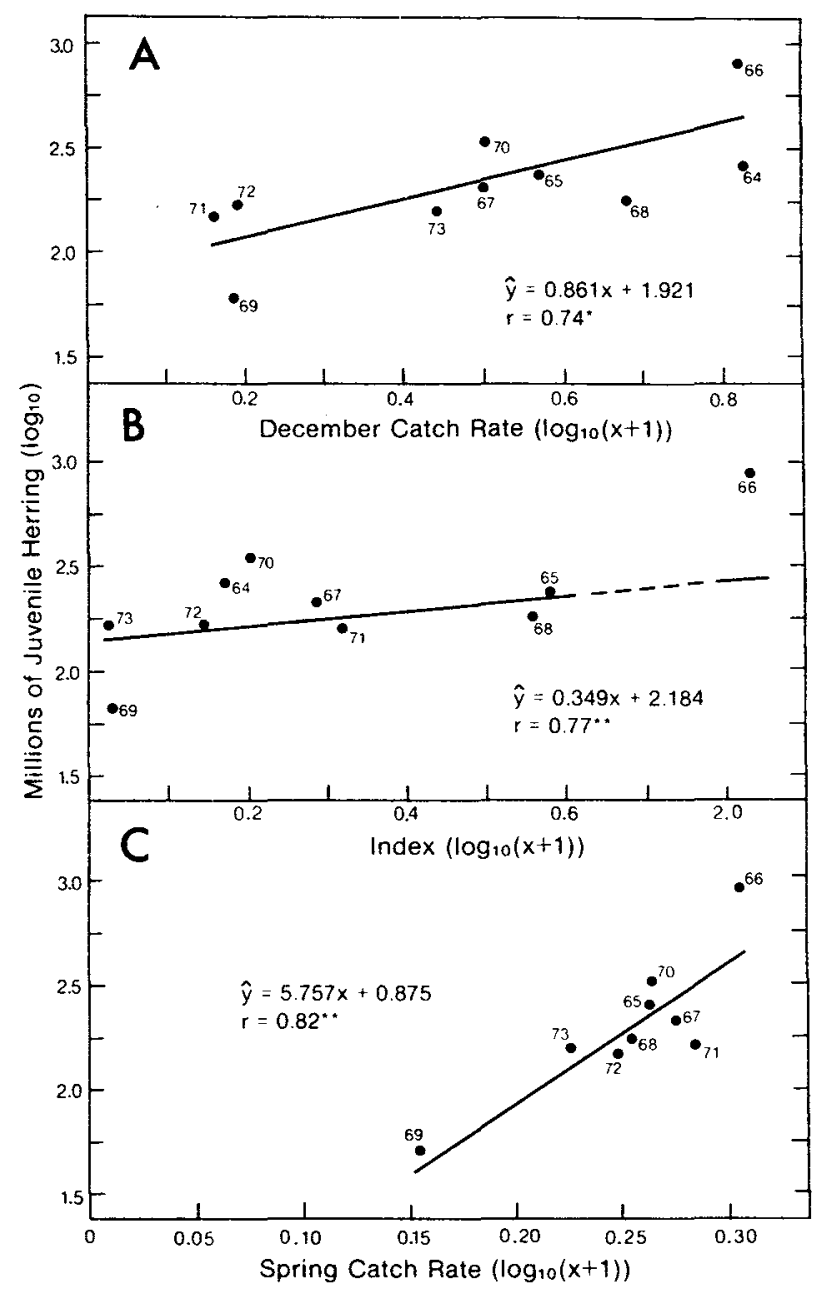

Fig. 14. Relationships between the catches of juvenile (age 2) herring in coastal Maine waters for the 1964-73 year-classes and (A) mio-December catch rates of larvae; (B) spring survival index derived by applying winter survival rates to the midDecember catch rates; and (C) spring catch rates of larvae. [Data were logarithmically transformed as indicated for analysis; asterisks denote significance at the $5 \%$ level (*) and the $1 \%$ level ("*) of probability.] 
TABLE 8. Index of anticipated relative abundance of juveniles in spring for the 1964-73 year-classes and subsequent catches of these year-classes in the Maine fishery.

\begin{tabular}{lcccccc}
\hline \hline $\begin{array}{c}\text { Year- } \\
\text { class }\end{array}$ & $\begin{array}{c}\text { Estimated } \\
\text { abundance } \\
\text { (15 Dec) }^{\mathbf{a}}\end{array}$ & $\begin{array}{c}\text { Winter } \\
\text { survival } \\
\text { rate }^{\mathbf{b}}\end{array}$ & $\begin{array}{c}\text { Index of } \\
\text { juvenile } \\
\text { abundance }\end{array}$ & \multicolumn{2}{c}{ Juvenile catch (106) } \\
\cline { 5 - 7 } & Age 2 & Ages 1-3 \\
\hline 1964 & 5.75 & 0.033 & 0.190 & 292 & 454 \\
1965 & 2.74 & 0.214 & 0.586 & 268 & 441 \\
1966 & 5.75 & 0.379 & 2.179 & 877 & 1,148 \\
1967 & 2.16 & 0.133 & 0.287 & 216 & 269 \\
1968 & 3.88 & 0.145 & 0.563 & 183 & 206 \\
1969 & 0.58 & 0.051 & 0.030 & 62 & 71 \\
1970 & 2.16 & 0.093 & 0.201 & 339 & 520 \\
1971 & 0.47 & 0.691 & 0.325 & 155 & 208 \\
1972 & 0.53 & 0.273 & 0.145 & 175 & 211 \\
1973 & 1.59 & 0.016 & 0.025 & 172 & 313 \\
\hline
\end{tabular}

a Larval catch rates in Table 2 adjusted to 15 December.

${ }^{b}$ From last column of Table 3

(Table 4) was not followed by a large increase in the harvest of juveniles (Fig. 13). The unusually large larval catch rate in the autumn of 1977 (Fig. 10) was followed by an excellent harvest of this year-class, but this was not predictable from the high winter mortality (Table 3) or from the low spring abundance (Table 4). The harvest of the 1978 year-class was low (Fig. 13) but perhaps not as low as might be expected from the unusual scarcity of larvae of this year-class from the survey data (Fig. 10, Table 4).

\section{Discussion}

\section{Larval dispersal}

The results from the autumn surveys in 1972 support previous inferences of larval drift along the Maine coast. The distributions of larval herring (Fig. 4-6) show the movement of larvae to inshore waters as indicated by their accumulations at the mouths of estuaries and embayments and a prominant east to west drift of those larvae hatched in the coastal area of eastern Maine. There was perhaps a slight southerly drift of larvae hatched in the western Maine area, although most of these larvae appeared to move inshore near their hatching sites. Previous hydrographic studies indicate alongshore currents from west to east, but these currents are complex with shoreward incursions which provide opportunities for larvae to enter the embayments and estuaries (Graham, 1970a; Parker and Garfield, MS 1981a). A relationship between these currents and larval dispersal has been established for the spring period. Graham et al. (1972) found that the distribution of larval herring was associated with that of salinity when spring estuarine outflow caused strong dynamic pressure gradients. With a lessening of river discharge in the autumn and winter, this association was not demonstrable. The drift of larvae from eastern to western Maine in autumn was assumed because some larvae captured in the western sector were larger than those newly hatched in that sector (Graham et al., 1972). This assumption has been recently supported by the identification of groups or cohorts of larvae through counts of rings in the otoliths (Graham and Joule, MS 1981). The presence of larvae, which formed their first otolith ring in late August and early September, in both Sullivan Harbor of eastern Maine and Sheepscot River estuary of central Maine suggested a westward drift from eastern Maine, because hatching in central and western Maine does not usually begin until mid- to late September.

The dispersal of larvae hatched late in the autumn (November) along the coast was not specifically investigated, but late hatching occurred on a small scale in eastern Maine in 1971 (Graham et al., MS 1972) and in western Maine in 1972 (Fig. 4). Although late hatching was subsequently intensified, the associated catches of larvae were smaller than those in early autumn (Fig. 9-10). One explanation for intensified late spawning is that the reduction in the populations of adult herring in the Gulf of Maine caused a change in their spawning behavior. The advent of the winter movement of larvae into the Sheepscot River estuary in 1974 (Fig. 9) followed closely the depletion in 1972 of the accumulated stock of adult herring in the western Gulf of Maine (Anthony and Waring, 1980). However, this temporal change in behavior did not indicate changes in either spawning sites or patterns of larval drift. Eastern Maine was surveyed in 1980 to determine whether spawning areas and larval drift were similar to those of the early 1970's (Graham and Joule, MS 1981). It was found that the same general spawning area off Machias Bay was still being utilized and that the drift of larvae had characteristics similar to those observed in September 1972 (Fig. 4).

Shaw (MS 1981) presented data that demonstrated the ability of larval herring to thoroughly utilize the inshore nursery grounds of the Maine coast. Prior to 1974, a causeway and bridge existed between Westport Island and the mainland across a narrow channel of Montsweag Bay adjacent to the Sheepscot River estuary (Fig. 2). The narrow opening of this causeway obstructed the tidal exchange and created a circulation not conducive to transport of larval fish. The causeway was removed in late 1974 to permit greater dispersal of hot-water effluent from a newly constructed nuclear power plant. Shaw (MS 1981) found that the catch rates of larval herring from buoyed and anchored nets in Montsweag Bay were significantly greater during 3 years of study following removal of the causeway than in the preceding 4-year period. He also compared catch rates of larvae in Montsweag Bay with those in the adjacent confluent Sheepscot River estuary, noting that they were much lower in the bay than in the estuary prior to removal of the causeway but were similar in both areas following its removal. The 
increase in abundance of larvae in Montsweag Bay was apparently not accompanied by a decrease in abundance in the Sheepscot River estuary. Presumably, the bay and estuarine nursery areas now accommodate more larval herring than before removal of the causeway with its restricted circulation.

\section{Mortality}

During the period of development from hatching to metamorphosis, herring larvae experience several phases of mortality which decrease progressively in intensity. Within days after hatching, the yolk sac is absorbed and the larva must find food or perish (Blaxter, 1965). Approximately $75 \%$ of the larvae may die within 4 days after hatching (Graham and Chenoweth, 1973). Abundance of the surviving larvae, which enter the inshore areas along the Maine coast, reaches a high peak within 4-5 weeks and then declines to a low level by early winter (Graham et al., 1972). The winter death rate appears to be much lower, with estimates of 33-99\% over a 3-month winter period (Table 3). Spring mortality is probably quite low, as the large surviving larvae are in excellent condition (Chenoweth, 1970). They have a mouth gape capable of ingesting a large array of food particle sizes (Sherman and Honey, 1971).

Specific estimates of mortality are difficult to make when larvae are aggregated and moving, especially in autumn and spring. Results of sampling with nets in the Sheepscot River estuary indicate that an individual aggregation of larval herring may be $2-3 \mathrm{~km}$ long and 10-20 $\mathrm{m}$ deep. In the spring, the larvae are sufficiently large to appear as echo-sounding traces, one such aggregation of large larvae (mode at $40.5 \mathrm{~mm} \mathrm{SL}$ ) having been recorded (Graham and Davis, 1976) as being $10 \mathrm{~m}$ deep with a density of $47-61$ larvae per $100 \mathrm{~m}^{3}$ of water strained. Such spring aggregations disapear as the larvae complete metamorphosis and begin schooling as juveniles by late spring. In contrast, the autumn aggregations are reduced through attrition by mortality.

Two types of mortality may be important features of the ecology of larval herring in the Sheepscot River estuary during autumn and winter. The first may be induced by overcrowding and the second may reflect the vicissitudes of the environment.

The first type of mortality is indicated by the agreement between the deviations of catch rate and weight (residuals) of the 1976 year-class (Fig. 12), providing a possible explanation for the decline following each of the three major peaks in catch rate. The estuary is like a funnel, concentrating the larvae in an ever-decreasing volume of water as they are moved landward and culminating ultimately in a high concentration of larvae in the narrow channel near Wiscasset (Fig. 1). Frequently, more than one aggregation of larvae is present in the channel (Graham, 1972a). The number of larvae may exceed the carrying capacity of the channel, and the larvae may become debilitated through starvation since a reduction in mean weight usually accompanies each peak in abundance. The subsequent decrease in catch rate is indicative of mortality, because larval herring do not move out of the estuary in autumn and winter. Exceptions to this explanation would occur when the number is reduced to or below the carrying capacity of the channel, as indicated by data of 4 October and 25 January for the 1976 year-class (Fig. 12). It is unlikely that the winter carrying capacity of the channel is affected by grazing of larvae during the preceding autumn, because tidal mixing should replenish any autumnal depletion of larval forage in the open-ended channel.

The 1978 year-class appeared to exhibit some of the features of the 1976 year-class (Fig. 12), the deviations of catch rate and weight showing a similar pattern of decline from mid-November to mid-December. At the end of this decline and with the entrance of the second group of larvae ( $D$ in Fig. 10), the weight deviation became positive and declined again. This second decline in mean weight accompanied a retardation or cessation of growth in larval length, as indicated by the otolith study of Townsend and Graham (1981). The catch rate and mean weight data gathered during October and early November showed little similarity of trends. A significant anomaly was the large negative weight deviation in early November when the catch rate was high due to the addition of larvae from group $A$ (Fig. 10). The relative decline in weight at that time coincided with the loss of larger larvae from groups $B$ and $C$. The loss of larvae from an entire size mode in November was reported previously by Graham et al., (1972). The reason for this loss is not known, but it was assumed that mortality rather than larval migration was responsible.

Graham et al. (1972) suggested that autumnal mortality might not reduce the abundance of larvae to approximately the same level along the coast by early winter of each year. Some support for this suggestion is indicated if autumnal mortality results from overcrowding. Often, more than one aggregation of larvae is present in the Sheepscot River estuary (Graham, 1972a) and in other estuaries and embayments (Graham et al., 1972). If the abundance of larvae exceeds the carrying capacity of the estuarine channel, additional aggregations (or their equivalent) may be lost through mortality. The considerable decline in catch rate of about 75 larvae per $100 \mathrm{~m}^{3}$ in only 20 days in October 1977 (Fig. 10 and 12) may be an example of such loss. Under such circumstances, the dispersal of 
many aggregations of larvae over many embayments and estuaries along the coast, as indicated in Fig. 4-6, would tend to increase the standing crop of larval herring by early winter, whereas the concentration of many aggregations within a small area of the coast would tend to decrease the standing crop.

The second type of mortality is indicated by the winter catch rates and mean weights of the 1977 yearclass (Fig. 12). In that winter, there were no peaks in catch rate and no agreement with larval weights was evident, although the average deviation of weight declined with a gradual decrease in catch rate. A similar monthly decline in condition of larvae in the 1960's was observed by Chenoweth (1970). The extremely large negative deviation in weight at the end of February for the 1977 year-class was also evident for the 1976 year-class but not for the 1978 year-class, in which growth in length resumed after a cessation in late January to early February (Townsend and Graham, 1981). A study of the Damariscotta River estuary in the Boothbay Harbor area indicated that the food of larval fishes became abundant during late February 1979 (Townsend, MS 1981).

Increased winter mortality appears to be associated with poor condition of the larvae in winter. Chenoweth (1970) observed a reduction in the monthly condition factor for the 1964-67 year-classes of larvae in the inshore area of central Maine. A comparison of this reduction with mortality rates for larvae in the Sheepscot River estuary demonstrated that mortality increased with a decrease in condition factor (Graham and Davis, 1971). This comparison was later extended to the 1968 and 1969 year-classes (Graham et al., 1972), resulting in agreement for the 1968 year-class but not for the 1969 year-class. It is therefore possible that causes other than those associated with debilitation might be involved.

The causes of winter larval mortality in the Sheepscot River estuary are not known. Lethally low temperature was indicated as the major cause of mortality for the 1964 year-class (Chenoweth, 1970; Graham and Davis, 1971), and starvation was considered a major factor for other year-classes because of a general reduction in food for larvae during winter (Sherman and Honey, 1971). K. Sherman (pers. comm.) reported that the larvae contained a parasitic nematode which might debilitate or kill them. Dow (1976) suggested that temperature has been the principal long-term environmental regulator of species (including herring) abundance and availability in the Gulf of Maine. Whatever the cause, the relationships shown in Fig. 12 indicate that winter mortality is probably a determinant of the size of larval year-classes of herring just before their metamorphosis in the spring.
Intraspecific competition may evoke, through starvation or debilitation, much of the mortality of larval herring when they enter the estuaries and embayments, but this may be offset by certain advantages. The movement of larvae inshore after hatching removes them from possible cannibalism by their parents. Data from examination of stomach contents of various fishes captured in the nets indicate that, at least during the night, predation on larvae in estuaries is not appreciable. Competition with tychoplankters for space in the estuaries may be moderated by progressive changes in the times of sunrise and sunset, which are not synchronized with the timing of the tidal cycle and the extent of residual tidal flows. Thus, tychoplankters may encounter an aggregation of larvae during their ascent into the water column in one night but not in the next.

Alldredge and King (1980) found three major patterns in the movement of demersal zooplankton (tychoplankton) in coastal waters of the Gulf of Mexico. Some emerged at dusk, some only during moonlight and others during the dark phases of the moon. Cumaceans emerged at dusk and remained in the water column throughout the night. Amphipods emerged on both moonlit and moonless nights, depending on the species. Copepods, cyclopoids and harpacticoids emerged on dark nights. In the present study, cumaceans (Table 7) were more closely associated with the distribution of larval herring than any other group. Alldredge and King (1980) indicated that demersal zooplankton escape predation during their emergence, but little is known about their activities in the water column. The role of some tychoplankters in the Maine estuaries and embayments may be saprophagous, consuming dead and dying herring larvae.

\section{Larval herring abundance indices}

The failure to develop a reliable technique for the prediction of the Maine harvest of juvenile herring from larval abundarice indices was probably related to the many changes that occurred in the herring stocks and fisheries during the period of this investigation. The severe decline in the harvest of juveniles extended from 1958 to 1971 when the catch decreased from 73,860 metric tons to 12,385 tons (Anthony, MS 1972). This decline did not coincide with the development of the fishery for adult herring on Georges Bank and in the western Gulf of Maine. Although catches in these areas were large in the 1960's, the stock of spawning fish remained high (Anthony and Waring, 1980). It was suggested that the decline in the Maine catch of juveniles was caused by relatively low survival of larvae in the 1960's, associated with unfavorable environmental conditions. In the early 1970's, the fishery for adults peaked in the western Gulf of Maine, and the large 
reduction in spawning stock coincided with the low winter abundance of the 1971 and 1973 year-classes. However, the estimates of stock size after 1971 are uncertain (Anthony and Waring, 1980). Because the fishery in the early 1970's occurred mainly on spawning concentrations, the act of fishing could have disrupted spawning activity by reducing the number of eggs deposited and the number of larvae hatched, independently of the spawning stock size. For this reason, the Government of Maine included closure of spawning grounds in its herring management plan (Anon., 1978). Anthony and Waring (1980) stated that disrupted spawning activities might have led, in part, to the decline of the Georges Bank herring stock.

The interrelationships of the various herring populations in the Gulf of Maine during the 1960's and 1970 's are not well known. Anthony and Waring (1980) demonstrated a relationship between the Maine fishery on juveniles and the Georges Bank fishery on adults. Although they obtained a statistically significant relationship, the prediction equation overestimated the abundance (at age 3 ) of the 1968 year-class by $82 \%$ and underestimated the size of the 1969 and 1970 yearclasses by 64 and $58 \%$ respectively. They did not offer an explanation for the large deviations relevant to the 1968 and 1969 year-classes, but they suggested that the coastal harvest of the 1970 year-class was potentially greater, based on reports by fishermen that some of the herring remained offshore and were therefore not available to the inshore fishing gear. Such unavailability may also be reflected in the movement of juvenile herring from eastern Maine to New Brunswick, Canada. Although the 1976 year-class appeared to have been abundant as larvae in coastal Maine waters in the spring of 1977 (Table 4), it did not produce a large Maine harvest of juveniles in 1978. However, there was a very large harvest of this year-class in adjacent Canadian inshore waters. A comparison of the various larval abundance indices for Maine waters with the combined harvests of juveniles from the adjacent U. S. and Canadian inshore waters did not reveal any agreement.

The effect of the western Gulf of Maine and Georges Bank fisheries on the production of herring in coastal Maine waters is considered here because of the migrations of adult and perhaps larval herring. Adult herring migrate from the Maine coast in autumn and enter the winter fishery in Massachusetts waters (Speirs, MS 1977; Chenoweth et al., MS 1980). In spring, the survivors return to the Maine coast where they spawn in late summer and autumn (Almeida and Burns, MS 1978; Stobo, MS 1976). The proportion of the Maine stock participating in this migration is not known. Some larval herring may also be transported from other areas and contribute to the Maine fishery.
The evidence for such a contribution through larval movement across the deep Gulf of Maine waters was reviewed by Graham et al. (1972), Boyar et al. (1973) and Anthony and Waring (1980), but little direct evidence, such as the distribution of larvae across the Gulf, was found. However, Messiah et al. (1971) reported the capture of small numbers of larvae distributed from Georges Bank to about $28 \mathrm{~km}$ off the eastern coast of Maine during February 1967, April 1969 and April 1970. Within the same area, Davis and Norris (MS 1976) found larval herring distributed from Georges Bank to about $55 \mathrm{~km}$ off the coast during May 1976. Certain of their transects were sampled about 3 weeks later, but few larvae were caught. The authors accounted for this difference in catch by suggesting a migration from the bank. To cross the Gulf from Georges Bank to the Maine coast, the larvae must be transported by currents. In the eastern part of the Gulf, the opportunity for larval transport may occur in the spring, when the anti-clockwise gyre of the Gulf is active, but not in February. In the western part of the Gulf, the gyre would transport the larvae westward and southward along the coast. However, the system of currents near the coast is very complex, with shoreward intrusions of water extending from well offshore (Graham, 1970a; Parker and Garfield, MS 1981b). If a spring movement of larvae from Georges Bank to the Maine coast occurred regularly, a significant decrease in the numbers of larvae would have been evident during the decline of the Georges Bank and Gulf of Maine spawning populations in the 1970's.

The fishery for adult herring (age 4+) along the Maine coast has never been very large, and in only one instance did fishing perhaps influence the production of larval herring. Catches averaged about 3,450 tons annually between 1967 and 1979, with peak harvests in 1967 (7,050 tons), 1971 (5,930 tons) and 1978 (9,180 tons). The harvest in the summer of 1978 was a record for the coastal fishery and occurred prior to closure of the fishery to permit adult fish to spawn. Most of the fish were caught in the central and western areas (Fig. 1), with a large catch of 2,860 tons near the Sheepscot River estuary. This catch consisted mainly of 8-yearold herring (1970 year-class), the females of which carry approximately three times as many eggs as younger (4-5 yr) age-groups which were not as abundant in the harvest. The reduction of the adult population prior to spawning probably led to the low catches of 1978 year-class larvae in the central area (Table 4). The spring catch of larvae was somewhat higher in other areas, especially in eastern Maine where a large portion of the coastal waters was closed to purseseining from 10 April to 15 October 1978. This closure together with late spawning in 1978 may have resulted in the production of larger numbers of larvae in eastern Maine and consequently a larger catch of the 1978 
year-class as 2-year-olds than would be expected from the larval abundance indices for the Sheepscot River estuary (Fig. 10).

Despite the reduced population of young spawning adults in the 1970's, there was a large production of larval herring in the autumn of 1977 (Fig. 10) which contributed to the very large catch of this year-class as 2 -year-olds in the coastal Maine fishery of 1979. However, the large catch of the 1970 year-class in the coastal fishery of 1978 indicated that these fish as 7 -year-olds must have been abundant along the coast in 1977. A successful spawning of the 1970 year-class with its large average fecundity $(140,000$ eggs per female) was probably responsible for the very large number of larvae present in the autumn of 1977 (Fig. 10). However, the apparent high winter mortality and very low spring catch of 1977 year-class larvae in the central area (Fig. 11) conflicts with subsequent evidence that this year-class was abundant as 2-year-olds in the coastal fishery. Therefore, the spring catch rate for larvae of this year-class in the central area (Table 4) was apparently not representative of abundance along the entire coast, and it is likely that the catch rates in the eastern and western areas also were greatly underestimated.

\section{Conceptual model of larval production}

The development of a model, to illustrate events that contribute to the final year-class strength of larval herring just prior to metamorphosis, depended on two assumptions: (a) the basic determinants of year-class strength are the levels of larval abundance following a density-dependent phase of mortality in autumn and a density-independent phase of mortality in winter, and (b) these basic determinants may be modified by late spawning and the nature of the distribution of larvae along the coast after hatching in the autumn.

Figure 15 depicts a model of the progression of larval herring abundance in a given estuary or embayment during autumn and winter. Some portions of the curves were fitted mathematically (Graham, MS 1980b) and others by eye. The smoothed decline in the autumn was calculated from 5 years of catch rate data from buoyed and anchored nets in Sheepscot River estuary. The February decline was calculated from catches of the 1976 year-class (Fig. 10). The smoothed decline of winter catch rates (December-March) of the autumn aggregations was based on average mortality estimates (Table 3 ). In addition to the catch rate (number per $100 \mathrm{~m}^{3}$ of water strained), a rough estimate of the relative number of larvae was provided for the model (Fig. 15) by multiplying the catch rate by an estimate of the volume of water $\left(55 \times 10^{6} \mathrm{~m}^{3}\right)$ in the sampling area of the Sheepscot River estuary (Graham and Davis, 1976).

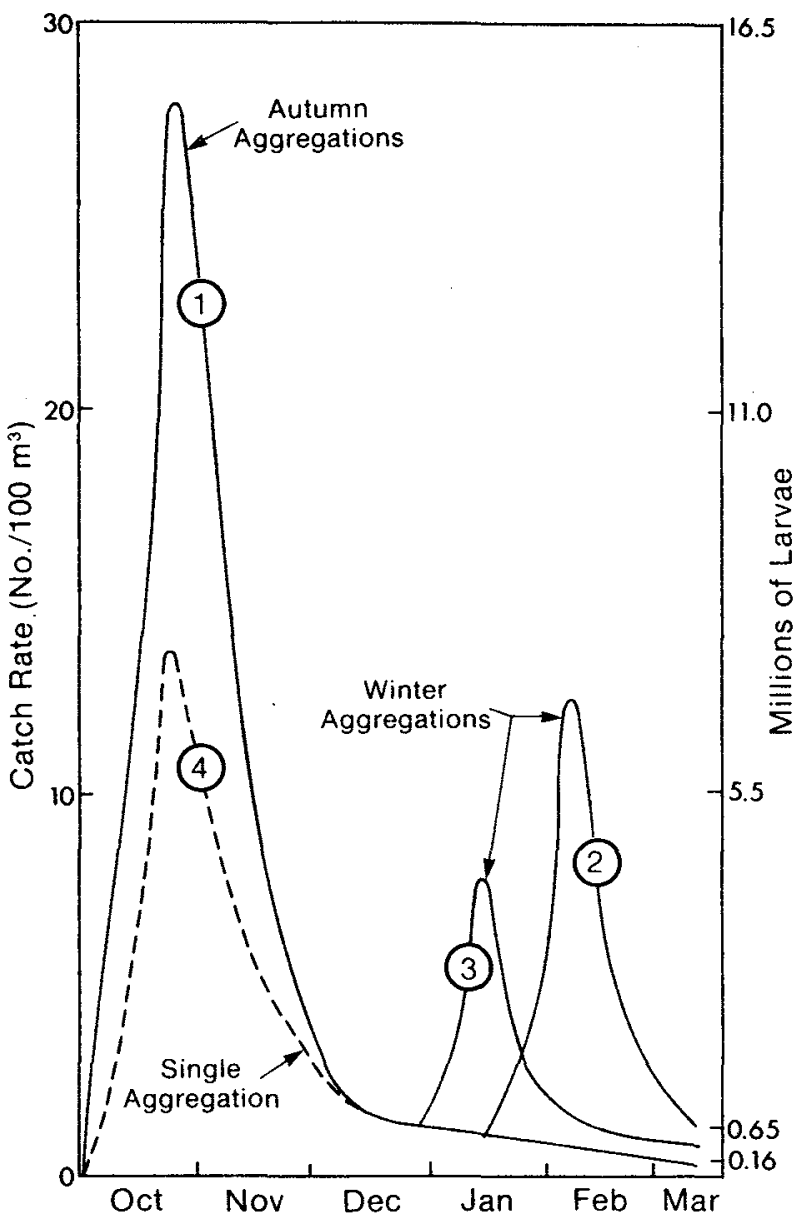

Fig. 15. Conceptual model of larval herring production in inshore Maine waters. (Curves are numbered to facilitate reference to them in the text.)

From the model, the events leading to year-class strength of larval herring can be followed. Aggregations of larvae enter an estuary (or embayment) in autumn (Fig. 15, curve 1). They are retained there and a peak in abundance occurs in late October. Overcrowding results in a rapid decline in abundance, very likely caused by starvation. The total mortality probably exceeds this rate of decline because larvae from early autumn hatching continue to move into the estuary until early December. The winter mortality is densityindependent and much less severe than in the autumn. In the model, the catch rate for curve 1 is reduced from $1.5 / 100 \mathrm{~m}^{3}$ in mid-December to $0.3 / 100 \mathrm{~m}^{3}$ by early March, when only about 160,000 larvae of this group remain in the estuary. When late spawning occurs, aggregations enter the estuary as late as February (curve 2). As in autumn, this peak is followed by density-dependent mortality, but the densityindependent phase of mortality is largely precluded by the onset of spring. The abundance of this group $(650,000$ larvae) is about four times that which results 
in the absence of late spawning. When winter aggregations enter in late December or January (curve 3), density-independent mortality occurs but it persists for a shorter period than in the autumn aggregations. For the spring production of larvae from autumn aggregations to be greater than that shown for curve 1 , the abundance must be higher than that indicated at the beginning of the density-independent phase in mid-December. This would not result from an increase in size of the autumn aggregations, due to densitydependent effects, but rather from the influx of later aggregations, particularly if the number surviving from the initial autumn influx is reduced below the carrying capacity of the estuary. Under such circumstances, the later the winter aggregations enter the estuary, the greater will be their contribution to spring abundance. Also, an early spring would shorten the winter period and thus enhance the survival of larvae (Graham and Joule, MS 1980).

The second autumn aggregation depicted in the model (Fig. 15, curve 4) represents the entrance into the estuary of a much smaller group with coincident distribution of residual aggregations to other estuaries or embayments unoccupied by larvae. If two aggregations were involved in such a distribution under similar environmental conditions, the resulting spring abundance would be doubled, i.e. 160,000 larvae in each estuary.

This model does not consider all larvae hatched along the coast. Some do not enter the estuaries and embayments until spring. A comparison of inshore and coastal catch rates in autumn and winter by Graham et al. (1972) indicated that most larvae entered inshore waters in the autumn, but data in Table 3 indicate that the proportions of larvae moving inshore would be difficult to estimate unless sampling is greatly intensified throughout the entire region. The absence of data on mortality of larvae that overwinter offshore precludes a comparison with estuarine aggregations. However, the density-dependent mortality of offshore larvae may also be very high since they occur in large "patches" (Graham et al., MS 1973). Studies in offshore waters may provide estimates of mortality within large larval patches (Potter and Lough, MS 1980).

The model attempts to separate densityindependent and density-dependent mortalities, an unusual separation according to Hunter (1976). The nature of larval dispersion along the embayments and estuaries is presumed to interact with the major causes of mortality (starvation and predation) to affect the survival of a given year-class (Hunter, 1976). Indeed, the efficiency of dispersion of larval aggregations along the coast might be as important as the rates of starvation and predation in the various nursery areas.
However, the "critical period" concept, as broadly defined by May (1974), is not included in the model, i.e. that most larval mortality occurs over a very short period during early larval development. More specifically, Hjort (1926) suggested that the period occurs shortly after the exhaustion of yolk by the larvae and the consequent need to begin feeding. Certainly, mortality in larval herring is high during this brief period (Dragesund and Nakken, 1971; Graham and Chenoweth, 1973). If such mortality occurs in larval herring which do not enter the estuaries, it may be masked by the relatively low mortality over the entire winter. May (1974) and Ware (1975), in their reviews of mortality in larval fishes, suggested respectively that, instead of searching for a brief catastrophic mortality during the life history of the larvae, it might be more profitable for the investigator to consider how "... the characteristics of reproduction and early development reflect the overall adaptation of the species to its environment" and to propose that larval fish "... are probably subject to the same basic foraging and energetic constraints that control the overall production and size composition of pelagic communities".

\section{Forecasts of recruitment}

The purpose of the research described in this paper was to anticipate the strength of individual yearclasses of juvenile herring (primarily age 2) recruiting to the Maine fishery. The first forecast was made for the recruitment of 2-year-old herring to the fishery in 1973. It anticipated that recruitment of the 1971 year-class would be larger than the previous seven, including the 1966 year-class (Fig. 13), this expectancy being based on low winter mortality (Table 3 ) and the high spring catch rate (Table 4). However, this forecast proved excessively optimistic. No forecast was made for the 1974 fishery.

Forecasting began again for the 1975 fishery (Table 9), the prediction being based primarily on high winter mortality of the 1973 year-class of larvae and the low spring catch rate (Tables 3 and 4 ). The spring catch rate of larvae approached that for the 1969 year-class, and so the 1971 harvest was chosen as the lower limit. The size of the 1969 harvest was chosen as the upper limit of the forecast. Although the actual harvest in weight exceeded the upper limit of the forecast by $40 \%$, the estimated number of juveniles caught fell within the range of the forecast due to differential growth among the year-classes.

Larvae of the 1974 year-class were more abundant in the Sheepscot River estuary than previously, especially in early winter (Fig. 9), and it was assumed that this increase occurred in other estuaries and embayments along the coast. Although the forecast was conservative, it was considered to be minimal, with the 
TABLE 9. Catches of juvenile herring (age 2) in relation to forecast by the Maine Department of Marine Resources for $1975-81$. (Catches are in metric tons and the numbers of fish are estimated. Application of reference fishery years are noted in the text.)

\begin{tabular}{|c|c|c|c|c|c|c|c|}
\hline \multirow[b]{2}{*}{$\begin{array}{l}\text { Fishery } \\
\text { year }\end{array}$} & \multirow{2}{*}{$\begin{array}{c}\text { Dominant } \\
\text { year- } \\
\text { class }\end{array}$} & \multirow{2}{*}{$\begin{array}{c}\text { Reference } \\
\text { fishery } \\
\text { year }\end{array}$} & \multicolumn{2}{|c|}{ Catch forecasts } & \multirow[b]{2}{*}{ Comments } & \multicolumn{2}{|c|}{ Actual harvest } \\
\hline & & & $\begin{array}{l}\text { Weight } \\
\text { (tons) }\end{array}$ & $\begin{array}{c}\text { Number } \\
\left(10^{6}\right)\end{array}$ & & $\begin{array}{l}\text { Weight } \\
\text { (tons) }\end{array}$ & $\begin{array}{c}\text { Number } \\
\left(10^{6}\right)\end{array}$ \\
\hline 1975 & 1973 & 1971,1969 & $2,800-6,700$ & $62-216$ & Catch may be closer to 2,800 tons. & 9,400 & 172 \\
\hline 1976 & 1974 & 1969 & 6,700 & 216 & $\begin{array}{l}\text { Forecast may be minimal. Should } \\
\text { exceed } 1975 \text { catch. }\end{array}$ & 13,200 & 310 \\
\hline 1977 & 1975 & 1976 & 13,200 & 310 & $\begin{array}{l}\text { Should approach } 1976 \text { catch. Stocks } \\
\text { may be increasing. }\end{array}$ & 18,500 & 430 \\
\hline 1978 & 1976 & 1973 & $>8,100$ & $>155$ & Minimum forecast will be exceeded. & 12,400 & 324 \\
\hline 1979 & 1977 & - & - & - & No forecast made & 25,800 & 747 \\
\hline 1980 & 1978 & 1975,1977 & $9,400-18,500$ & $171-430$ & Some additional recruitment possible. & 9,000 & 222 \\
\hline 1981 & 1979 & 1980 & $>9,000$ & $>222$ & $\begin{array}{l}\text { Should exceed } 1980 \text { catch. } \\
\text { High survival indicated. }\end{array}$ & 39,500 & 868 \\
\hline
\end{tabular}

suggestion that the harvest in 1976 might exceed that of 1975 , which it did.

Larvae of the 1975 year-class also entered the Sheepscot River estuary in winter, but in fewer numbers than in 1974 (Fig. 9). However, their entry continued into January, when a small peak in catch rate occurred. Because of this change in behavior, a firm forecast was not made, but it was suggested that the harvest in 1977 should approach that of 1976, which it actually exceeded. Furthermore, it was noted that the herring stocks "may be attempting a comeback", in view of the additional larvae entering the estuary in both 1974 and 1975.

The forecast of the 1978 harvest considered the possibility that late spawning in 1976 (Fig. 10) increased larval survival in the winter and contributed to the very large spring catch rate (Table 4). The 1971 year-class was also abundant in inshore waters, and the harvest in 1973 was taken as the lower limit of the forecast for 1978, but an upper limit was not set. The actual 1978 harvest of juveniles was about $50 \%$ larger than the minimum forecasted estimate in weight and double the estimate in numbers. A forecast of the 1979 harvest was not made, but the large catch (Table 9) indicated that recruitment was much higher than could possibly be predicted from data on high winter mortality (Table 3) and low spring abundance (Table 4) of the 1977 year-class, despite the high autumn abundance of larvae (Fig. 10).

Autumn catch rates of larvae in the Sheepscot River estuary indicated that the quantity of larvae hatched in 1978 (Fig. 10) was probably the lowest during the 1964-78 period. The spring catch rates (Table 4) indicated that this low level persisted in the central area of the coast. Under the assumption that late spawning would result in increased survival, the strength of the 1978 year-class was considered to be between that of 1975 when late spawning occurred and that of 1973 when late spawning did not occur. The forecast of the 1980 harvest was too high in terms of weight but the catch fell within the forecasted range in terms of numbers.

The 1981 harvest was forecasted to exceed the 1980 fishery. Both autumn and spring catch rates of the 1979 larval year-class were low but not as low as those of the 1978 year-class. This low abundance was perhaps countered by late spawning and unusually good physical condition of the larvae in February, thus indicating high larval survival. Preliminary estimates of the 1981 harvest indicated that the minimum forecast was greatly exceeded. Although these forecasts are sometimes imprecise, they are useful in formulating the annual management plan for the fishery on juveniles (Anon, 1978).

The results of the forecasts in Table 9 indicate that an understanding of the mechanisms controlling larval production is essential in determining recruitment to the fishery. Although larval abundance indices are obviously necessary, there appears to be little possibility of forecasting from them except during periods when the spawning stock is large and the samples may be more representative of the populaton of larvae. The hatching of large quantities of larvae increases the probability that they will enter the many estuaries and embayments along the coast and thus reduces the variability in estimating their standing crop from "socalled" representative estuaries during autumn and winter sampling. A large spawning stock might also exhibit the former spawning behavior and thus eliminate the additional variability introduced into estimates of winter mortality by intensified late spawning. Furthermore, a more even distribution of larvae along the coast in the spring might permit more representative sampling from selected areas.

Recognizing the sampling problems, information on larval condition, as collected in the 1960's by Chenoweth (1970), was again sought in the 1970's (Fig. 12) and continusd to the present. Information on age and 
growth was collected in 1978 and 1980 (Townsend and Graham, 1981; Graham and Joule, MS 1981). In 1980, studies in Sullivan Harbor were resumed and a coastal survey of eastern Maine was undertaken to check on the spawning success of herring (Graham and Joule, MS 1981).

Similarity in life-history characteristics of larval herring from the Gulf of Maine and Georges Bank indicates that winter mortality may be an important determinant of recruitment over a broad area. Seasonal changes in larval abundance during the 1960's in Maine waters (Graham et al., 1972) were similar to those in waters off Southwest Nova Scotia (Das, 1968) and on Georges Bank (Boyar et al., 1973). The environments of these areas are commonly influenced by weather conditions during winter, and yearly changes in oceanic conditions along the Maine coast and offshore in the Gulf of Maine are also related (Colton, 1968). Changes in spawning behavior occurred along the Maine coast, and Lough et al. (MS 1980) reported changes in spawning times on Georges Bank, namely, a delay in the onset of spawning in the 1970's and a shortening of the spawning season especially after 1975. Their calculations of $1.0-1.3 \%$ larval mortality per day on Georges Bank in 1971-73 are comparable to those for Gulf of Maine waters (0.4-1.9\%). Indeed, the similarity of winter larval mortality in a given year throughout the Gulf of Maine in the 1960's was perhaps the main reason, as suggested by Anthony and Waring (1980), for good and bad year-classes, irrespective of the size of the spawning stocks in the region.

In addition to providing a rationale for forecasting, the model in Fig. 15 suggests a basis for long-term management of the coastal herring fishery of Maine. In the early 1970's, the coastal herring stocks were probably adversely affected by the increased fishery on adult herring in the western Gulf of Maine. Under such stress, the coastal herring continued to be reasonably productive, whereas similar stress on the Georges Bank stock caused it to collapse (Anthony and Waring, 1980). Perhaps, the recruitment mechanism primarily responsible for the success of coastal herring under stress was the opportunity for larvae to utilize the inshore waters along the Maine coast as nursery grounds. Careful management of these inshore nursery grounds might favor a continuing fishery, even when management of the stocks is inadequate. Such management should give special attention to maintaining and increasing the opportunity for the retention of larvae in inshore waters. lles and Sinclair (1982) suggested that the maximum size of a given stock of autumn-spawning herring in the Northwest Atlantic is governed by the size of the area available for retention of its larvae. In view of the large coastal retention area and its probable efficient utilization by the larvae, the herring fishery of Maine has a large potential.

\section{Acknowledgements}

The research on larval herring began in 1962 under the auspices of the U.S. Bureau of Commercial Fisheries of the Department of the Interior, was continued under the U.S. National Marine Fisheries Service of the Department of Commerce, and is presently pursued (since 1973) under the Maine Department of Marine Resources. Over this period, a number of scientists and technicians assisted in the collection of data: Ronald Aho, Chris Adams, Bruce Bickford, Harold Boyar, Bill Brown, Stanley Chenoweth, Clarence Davis, Duane Orne, Kenneth Sherman, Gordon Trask, Paul Venno and George Vaughn.

I am particularly grateful to Vaughn Anthony, Jean Chenoweth and Lewis Lozier, who supplied data on juvenile herring for comparison with those of larval herring. Marie Willard of New England University and Susan Driscoll of Bates College assisted in studies of larval condition. Ruthanne Theran of New England University assisted in studies of tychoplankton. The Canadian Department of Fisheries and Oceans Biological Station at St. Andrews, New Brunswick, provided catch-at-age data for juvenile herring in waters adjacent to those of Maine.

\section{References}

ALLDREDGE, A. L., and J. M. KING. 1980. Effects of moonlight on the vertical migration patterns of demersal zooplankton. J. Exp. Mar. Biol. Ecol., 44: 135-156.

ALMEIDA, R. P., and T. S. BURNS. MS 1978. Preliminary results of the 1977 International Herring Tagging Program conducted on Jeffreys Ledge, the Great South Channel, and 12 miles east of Chatham, Massachusetts. U. S. Nat. Mar. Fish. Serv., Woods Hole Laboratory, Ref. Doc., No. 78-07, 31 p.

ANON. 1978. Herring regulations. Maine Dept. Mar. Resour., 2p.

ANTHONY, V. C. MS 1972. Population dynamics of the Atlantic herring in the Gulf of Maine. Univ. of Wash., Seattle, Wash., Ph. D. thesis, $266 \mathrm{p}$.

ANTHONY, V. A., and G. WARING. 1980. The assessment and management of the Georges Bank herring fishery. ICES Rapp. Proc.Verb., 177: 72-111.

BLAXTER, J.H.S. 1965. The feeding of herring larvae and their ecology in relation to feeding. Rep. Calif. Ocean. Fish. Invest., 10: 7888.

BOYEAR, H. C., R. R. MARAK, F. E. PERKINS, and R. A. CLIFFORD. 1973. Seasonal distribution and growth of larval herring (Clupea harengus L.) in the Georges Bank-Gulf of Maine area from 1962 to 1970. ICES J. Cons., 35: 36-51.

CHENOWETH, S. B. 1970. Seasonal variation in condition of larval herring in Boothbay area of the Maine coast. J. Fish. Res. Bd. Canada, 27: $1875-1879$.

CHENOWETH, S. B., M. A. HUNTER, and G. D. SPEIRS. MS 1980. Seasonal migrations and recruitment patterns of juvenile herring in the Gulf of Maine. Maine Dept. Mar. Resour., Lab. Res. Doc. $80 / 14,40 \mathrm{p}$.

COLTON, J. B. 1968. Recent trends in subsurface temperatures in the Gulf of Maine and contiguous waters. J. Fish. Res. Bd. Canada, 25: 2427-2437.

COLTON, J. B., and J. M. ST. ONGE. 1974. Distribution of fish eggs and larvae in continental shelf waters, Nova Scotia to Long Island. 
Amer. Geogr. Soc. Ser. Atlas Mar. Environ., Folio 23, 2 p. +11 pi.

DAS, N. 1968. Spawning, distribution, survival and growth of larval herring (Clupea harengus $L$.) in relation to hydrographic conditions in the Bay of Fundy. Fish. Res. Bd. Canada, Tech. Rep., 88: 1-129.

DAVIS, C. W., and T. L. NORRIS. MS 1976. Preliminary report on the distribution, catches and sizes of age 1 herring in the Gulf of Maine, Georges Bank and Nantucket Shoals during spring of 1976. ICNAF Res. Doc., No. 76, Serial No. 3937.

DOW, R. L. 1976. Effects of climatic cycles on the relative abundance and availability of commercial marine and estuarine species. ICES J. Cons., 37: 274-280

DRAGESUND, O. and O. NAKKEN. 1971. Mortality of herring during the early larval stage in 1967. ICES Rapp. Proc.-Verb., 160: 142146.

DUNN, O. J. 1964. Multiple comparisons using rank sums. Tecnometrics, 6: 241-252.

GRAHAM, J. J. 1970a. Coastal currents of the western Gulf of Maine ICNAF Res. Bull., 7, 19-31.

1970b. Temperature salinity and transparency observations, coastal Gulf of Maine, $1962-65$ Data Rep. U. S. Fish. Wildl. Serv., 42: $1-43$.

1972a. Retention of larval herring within the Sheepscot estuary of Maine. Fish. Bull., U. S., 70: 299-305.

1972b. Filtration efficiences of Boothbay Depressor nets. Fish. Bull., U. S., 70: 518-520.

MS 1980a. The effects of length of tow upon the catch of larval herring, Clupea haregnus, in coastal Maine. Maine Dept. Mar. Resour., Res. Ref. Doc. 80/1, 15 p

MS 1980b. Production of larval herring, Clupea harengus, along coastal Maine (1964-1978) and its relation to recruitment mechanisms of the sardine fishery. NAFO SCRDOC., No. 30, Serial No. N192.

GRAHAM, J. J., and S. B. CHENOWETH. 1973. Distribution and abundance of larval herring, Clupea harengus harengus Linnaeus, over egg beds on Georges Bank. ICNAF Res. Bull., 10: 141-149.

GRAHAM, J. J., and E. P. CREASER, Jr. 1978. Tychoplanktonic bloodworm, Glycera dibranchiata, in Sullivan Harbor, Maine. Fish. Bull. U. S., 76: $480-483$

GRAHAM, J. J., and C. W. DAVIS. 1971. Estimates of mortality and year class strength of larval herring in western Maine, 1964-67. ICES Rapp. Proc.-Verb., 160: 147-152.

1976. Estimates of the number of larval herring in a channel of the Sheepscot estuary: its value as a nursery ground. Bull. Maine Dept. Mar. Resour., 38: 1-17.

GRAHAM, J. J., and B. J. JOULE. MS 1980. Evaluation of the 1979 larval year class stength of coastal herring, Maine. Maine Dept. Mar. Resour., Res. Ref. Doc. 80/1, 21 p.

MS 1981. Evaluation of the 1980 year class of larval herring, Clupea harengus, along coastal Maine. NAFO SCR Doc., No. 140 , Serial No. N447.

GRAHAM, J. J., and D. B. SAMPSON. 1982. An experiment on the depth distribution of larval herring, Clupea harengus, in coastal Maine. NAFO Sci. Coun. Studies, 3; 33-38.

GRAHAM, J. J., and P. M. W. VENNO. 1968. Sampling larval herring from tidewaters with buoyed and anchored nets. J. Fish. Res. Bd. Canada, 25: 1169-1179.

GRAHAM, J. J., and G. B. VAUGHN. 1966. A new depressor design. Limnol. Oceanogr., 11: 130-135.

GRAHAM, J. J., S. B. CHENOWETH, and C. W. DAVIS. 1972. Abundance, distribution, movements and lengths of larval herring along the western coast of the Gulf of Maine. Fish. Bull., U. S., 70: 307-321.

GRAHAM, J. J., C. W. DAVIS, and B. C. BICKFORD. MS 1973. Autumn distribution, abundance and dispersion of larval herring, Clupea harengus harengus Linnaeus, along the western coast of the Gulf of Maine. ICNAF Res. Doc., No. 12, Serial No. 2914.

GRAHAM, J. J., C. W. DAVIS, S. B. CHENOWETH, and B. C. BICKFORD. MS 1972. Autumn distribution, abundance and dispersion of larval herring, Clupea harengus harengus Linnaeus, along the western coast of the Gulf of Maine in 1971. ICNAFRes. Doc., No. 7,
Serial No. 2690.

HJORT, J. 1926. Fluctuations in the year classes of important food fishes. ICES J. Cons., 1: 5-38.

HUNTER, J. R. 1976. Report of a colloquium on larval fish mortality studies and their relation to fishery research. U. S. Nat. Mar. Fish. Fish. Circ., 395: 1-8.

ILES, T. D., and M. SINCLAIR. 1982. Atlantic herring: stock discreteness and abundance. Science, 215: 627-633.

JAEGER, G. B., B. J. MCALICE, B. J. HOLLETT, C. A. RUBINO, and $M$ E. HUNTER. 1978. Macrozooplankton. In Environmental surveillance and studies at the Maine Yankee Nuclear Generating Station, 1969-1977. Maine Yankee Atomic Power Co., Augusta, Maine, Sect. 8.2, p. 1-74.

LECREN, E. D. 1951. The length-weight relationship and seasonal cycle in gonad weight and condition in perch. (Perca fluviatilis). $J$. Anim. Ecol., 20: 201-219.

LOUGH, R. G., G. R. BOLZ, M. R. PENNINGTON, and M. D. GROSSLEIN. MS 1980. Abundance and mortality estimates for sea herring (Clupea harengus L.) larvae spawned in the Georges BankNantucket Shoals area, 1971-1978 seasons, in relation to spawning stock and recruitment. NAFO SCR DOC., No. 129, Serial No. N203.

MAY, R. C. 1974. Larval mortality in marine fishes and the critical period concept. In The early life history of fish, J. H. S. Blaxter (ed.), Heidelberg, p. 3-19

MESSIEH, S. N., S. N. TIBBO, and L. M. LAUZIER. 1971. Distribution, abundance and growth of larval herring (Clupea harengus $L$.) in the Bay of Fundy-Gulf of Maine area. Fish. Fes. Bd. Canada Tech. Rep., 277: 1-18.

PARKER, C. E., and N. GARFIELD III. MS 1981a. Station data obtrained in northwestern Gulf of Maine coastal area, October 1979. Bigelow Lab. Ocean Sci., Boothbay Hr., Task Rep., 15: 117 p.

MS 1981b. Station data obtained in northwestern Gulf of Maine coastal area, April 1979. Bigelow Lab. Ocean Sci., Boothbay Hr., Task Rep., 11: 124 p.

POTTER, D. C., and R. G. LOUGH. MS 1980. Vertical distribution of herring larvae (Clupea harengus L.) on Nantucket Shoals, November 1977, collected by MOCNESS aboard Anton Dohrn 77-30. NAFO SCR DOC, No. 80, Serial No. N207.

POSGAY, J. A., and R. R. MARAK. 1980. The MARMAP Bongo zooplankton sampler. J. Northw. Atl. Fish. Sci., 1: 91-99.

SHAW, R. F. MS 1981. Seasonal composition, diversity, spatial distributions, and tidal retention and transport of ichthyoplankton in the Sheepscot River-Back River-Montsweag Bay estuarine system, Maine. Univ. of Maine at Orono, Maine, Ph. D. thesis, $288 p$

SHERMAN, K. 1970. Seasonal and areal distribution of zooplankton in coastal waters of the Gulf of Maine, 1967 and 1968. Spec. Sci. Rep., U. S. Fish. Wildl. Serv., 594: 80

SHERMAN, K., and K. A. HONEY. 1971. Seasonal variations in the food of larval herring in coastal waters of central Maine. ICES Rapp. Proc.-Verb., 160: 121-124.

SMITH, W. G., D. G. MCMILLAN, and A. WELL. MS 1980. The distribution and abundance of Atlantic herring larvae in the Gulf of Maine region as determined from MARMAP surveys, 1977-80. NAFO SCR DOC., No. 146, Serial No. N220.

SPEIRS, G. D. MS 1977. Herring tagging in western Gulf of Maine ICNAF Res. Doc., No. 50, Serial No. 5103

STOBO, W. T. MS 1976. Movements of herring tagged in the Bay of Fundy - update. ICNAF Res. Doc., No. 48, Serial No. 3834.

TOWNSEND, D. W. MS 1981. Comparative ecology and population dynamics of larval fishes and zooplankton in two hydrographically different areas on the Maine coast. Univ. of Maine at Orono, Maine, $\mathrm{Ph}$. D. thesis, $270 \mathrm{p}$.

TOWNSEND, D. W., and J. J. GRAHAM. 1981. Growth and age structure of larval herring (Clupea harengus) in the Sheepscot River estuary, Maine, as determined by daily growth increments in otoliths. Fish. Bull., U. S., 79: 123-130.

WARE, D. M. 1975. Relation between egg size, growth and natural mortality of larval fish. J. Fish. Res. Bd. Canada, 32: 2503-2512.

ZAR, H. 1974. Biostatistical analysis. Prentice-Hall Inc., Englewood Cliffs, N. J., $620 p$. 
